Portland State University

PDXScholar

1974

Physiological and Behavior Studies of Thelepus

Crispus and its Commensal Halosydna Brevisetosa

John B. Morgan

Portland State University

Follow this and additional works at: https://pdxscholar.library.pdx.edu/open_access_etds

Part of the Biology Commons

Let us know how access to this document benefits you.

Recommended Citation

Morgan, John B., "Physiological and Behavior Studies of Thelepus Crispus and its Commensal Halosydna Brevisetosa" (1974). Dissertations and Theses. Paper 2010.

https://doi.org/10.15760/etd.2009

This Thesis is brought to you for free and open access. It has been accepted for inclusion in Dissertations and Theses by an authorized administrator of PDXScholar. Please contact us if we can make this document more accessible: pdxscholar@pdx.edu. 
AN ABSTRACT OF THE THESIS OF Sohn E. Morgan for the Master of Science in Biology presented 28 June 1974.

Title: Physiological and Behavior Studies of Thelepus crispus and its Commensal Halosydna brevisetosa APPROVED BY MEMBERS OF THE THESIS COMMITTEE:
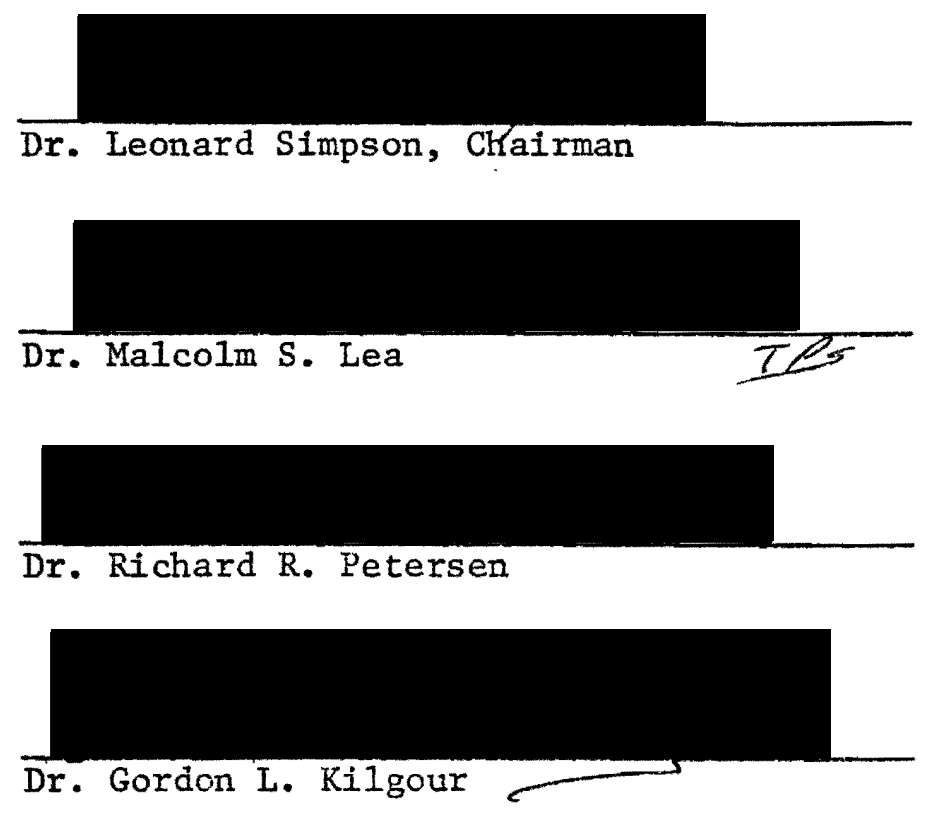

Chemical, physical and physiological interactions between the marine commensal scaleworm Halosydna brevisetosa Kinberg and its terebellid host, Thelepus crispus Johnson were investigated. In an experiment designed to test for chemical attraction between the host and commensal, Halosydna were unable to identify the arm in a U-tube choice apparatus leading to the host. In 50 trials, $54 \%$ of the commensals crawled into the flow of water from their hosts. Other observations showed that Halosydna made contact with the host by random encounter. After contact, commensals followed tentacles down into the host's tube and took up a characteristic position along the dorsum of the host's body wall. Halosydna's specific orientation in the host's tube may be 
the result of the current produced by the host rather than the presence of the host itself. Experiments with free-living forms of Halosydna revealed that these animals, not found in a commensal association, did not react to host tentacles, or to sea water containing several hosts.

In the intertidal, each Thelepus tube consistently harbored a single Halosydna of nearly proportional size to its host. When the wet body weights of 36 host-commensal pairs were plotted logarithmically against one another, the slope of a regression line through these points was 0.9167 and the high coefficient of correlation $(r=0.9408)$ was statistically significant $(<0.001)$. The smallest and largest hostcommensal pairs appeared to have the same proportion indicating that host colonization may be initiated early in post-embryonic development and these two annelids continue their growth together.

The respiration rates of pure (host and commensal in separate tubes) and mixed cultures (host-commensal pair in the same tubes) of these annelids were compared at two environmental temperatures $\left(12.5^{\circ} \mathrm{C}\right.$ and $16.5^{\circ} \mathrm{C}$ ). A logarithmic plot of oxygen consumption against the wet body weights $(\mathrm{g})$ of host and commensal specimens reveals that respiration rates $\left(\mathrm{m} 10_{2} /\right.$ animal/h) increase with increasing size. However, smaller individuals of both species consume oxygen at a faster rate (m1 $0_{2} / g / h$ ) per unit weight than do larger individuals of the same species. A comparison of the respiration data from the same organisms (at $12.5^{\circ} \mathrm{C}$ and $16.5^{\circ} \mathrm{C}$ ) indicates no significant difference in the rate of oxygen consumption between a number of host Thelepus in pure culture and the same host specimens with their commensals in mixed cultures. An Individual specimen of Halosydna consumes less oxygen than a host with which it is normadly found. Halosydna consumes an average of 
$23 \% \pm 9.87 \%$ S.D. (at $16.5^{\circ} \mathrm{C}$ ) to $33 \% \pm 6.06 \%$ S.D. (at $12.5^{\circ} \mathrm{C}$ ) of the total oxygen consumed in a mixed culture. The rates of oxygen consumption for both Thelepus and Halosydna also change with declining oxygen concentration.

Irrigation rates $\left(\mathrm{ml} \mathrm{H}_{2} \mathrm{O} / \mathrm{g} / \mathrm{h}\right)$ through the tubes occupied by host Thelepus were measured in the presence and absence of commensal Halosydna at $12.5^{\circ} \mathrm{C}$ and $16.5^{\circ} \mathrm{C}$. The volume of water pumped by various sized Thelepus was significantly reduced $(<0.01)$ when Halosydna occupied the same tube, indicating that the commensal plays a role in changing ventilation rates. These rates are depressed to a greater degree at $16.5^{\circ} \mathrm{C}(\overline{\mathrm{x}}=20.76 \% \pm 8.12 \%$ S.D. $)$ than at $12.5^{\circ} \mathrm{C}(\overline{\mathrm{x}}=14.58 \% \pm 7.54 \%$ S.D. $)$. No water movement was detected in tubes occupied by the commensal alone. 
PHYSIOLOGICAL AND BEHAVIOR STUDIES OF THELEPUS CRISPUS

AND ITS COMENSAL HALOSYDNA BREVISETOSA

by

JOHN B. MORGAN

A thesis submitted in partial fulfillment of the requirements for the degree of

MASTER OF SCIENCE

in

BIOLOGY

Portland State University

1974 
TO THE OFFICE OF GRADUATE STUDIES AND RESEARCH:

The members of the Committee approve the thesis of

John B. Morgan presented 28 June 1974.
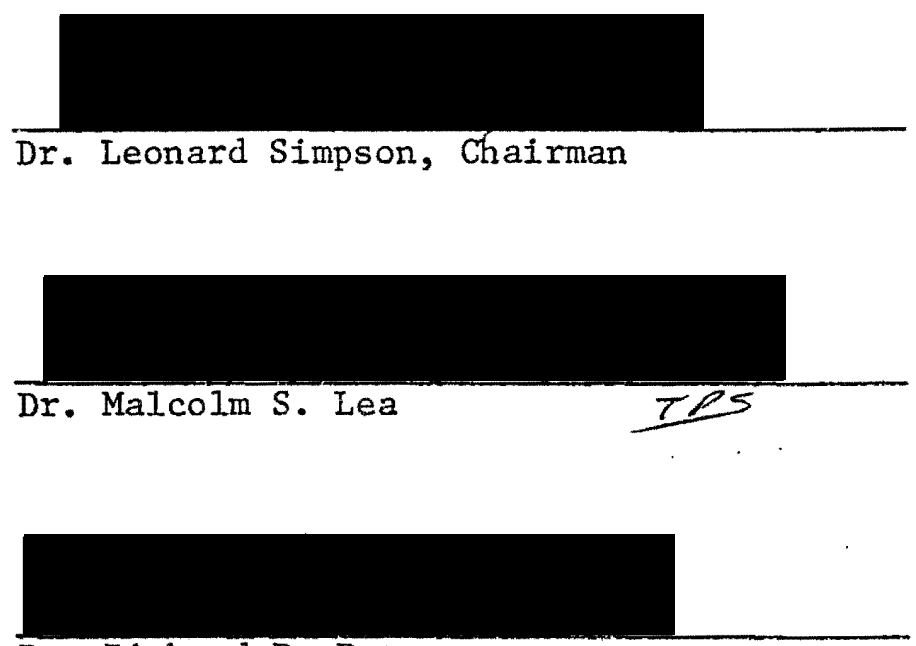

Dr, Richard R. Petersen

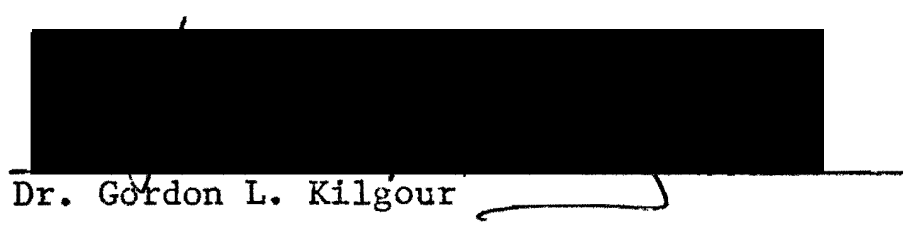

APPROVED:

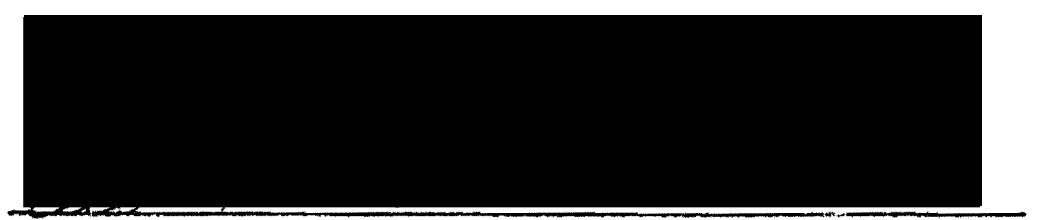

Earl Fisher, Jr., Head, Department of Biology

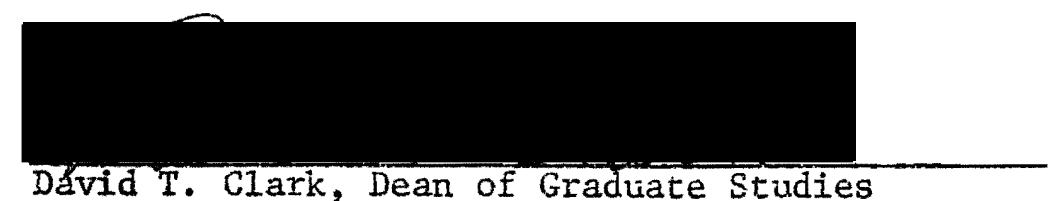

David T. Clark, Dean of Graduate Studies 
I wish to thank Jim Bain for his advice and electronic expertise as well as Jack Janacek and his staff for the construction of the respiration and irrigation chambers. The design of the irrigation chamber was developed with the assistance of Dr. Trygve P. Steen.

The oxygen probe and meter loaned by the U. S. Geological Survey were essential to this investigation and $I$ thank them for its use.

Dr. Quentin Clarkson and Bill Spurlund set up a special computer program to statistically process part of the data presented in this thesis. Their advice and time are greatly appreciated.

Part of the supporting data was gratefully received from Robert Garlick at the Oregon Institute of Marine Biology, Charleston, Oregon. My thanks also goes to Dr. Leonard Simpson who gave advice on the development and direction of my research as well as making suggestions on the organization and composition of the thesis. Dr. Malcolm Lea and Dr. Richard Petersen reviewed the thesis and offered constructive criticism on its form and content.

The illustrations in this thesis were drawn by my wife, Lorri. Her encouragement and understanding during this period of research and writing helped me immensely. 
Natural History $\quad 4$

METHODS AND MATERIALS $\quad \cdot \quad 8$

$\begin{array}{lr}\text { Collections and Culturing } & 8\end{array}$

$\begin{array}{lr}\text { Host-Commensal Weight Relationship } & 8\end{array}$

$\begin{array}{lr}\text { Test for Physiological Attractants } & 8\end{array}$

Observation of Behavior 11

Oxygen Consumption and Size $\quad 11$

$\begin{array}{ll}\text { Irrigation Rates of Commensal Pairs } & 13\end{array}$

$\begin{array}{ll}\text { RESULTS } & 16\end{array}$

$\begin{array}{lr}\text { Test for Physiological Attractants } & 16\end{array}$

$\begin{array}{ll}\text { Host-Commensal Weight Relationship } & 17\end{array}$

Host-Commensal Behavior 22

$\begin{array}{ll}\text { Oxygen Consumption vs Body Weight } 26 & 26\end{array}$

Irrigation Rates $\quad 35$

$\begin{array}{ll}\text { DISCUSSION } & 37\end{array}$

$\begin{array}{ll}\text { Physiological Attractants Commensalism } & 37\end{array}$

Host-Commensal Behavior within the Tube 40

Oxygen Consumption in Irrigation Rates in Commensals 41 
PAGE

BIBLIOGRAPHY 47 APPENDIX I 52 APPENDTX II 53 APPENDIX III 
I A Summary of Invertebrates Reported as Hosts to

H. brevisetosa.

Significance of Host Factor in $T$. crispus Attracting

Commensal $\underline{\mathrm{H}}$. brevisetosa.

III Regression Analysis of $\underline{T}$. crispus and $\underline{\mathrm{H}}$. brevisetosa

Wet Weights.

IV

Covarient Analysis of Oxygen Consumption $\left(\mathrm{mlO}_{2} / \mathrm{h}\right)$ as

a Function of Wet Body Weight in Thelepus and

Halosydna using Air Saturated Sea Water at $12.5 \%$

and $16.5 \%$ and a Salinity of $33.0 \%$ (for figure

5).

v Covarient Analysis of Weight-Specific Oxygen Consumption

$\left(\mathrm{m} 10_{2} / \mathrm{h}\right)$ as a Function of Wet body Weight in

Thelepus and Halosydna using Air Saturated Sea

Water at $12.5^{\circ} \mathrm{C}$ and $16.5^{\circ} \mathrm{C}$ and a Salinity of

$33.0 \%$ (for figure 6 ).

VI A Comparison of the Rates at Which Sea Water $(33.0 \% / 00)$

is Pumped ( $\mathrm{ml} \mathrm{H}_{2} \mathrm{O}$ /wet body weight/h) by host Thelepus

in the Presence and Absence of Commensal Halosydna

In the Host Tube at $12.5^{\circ} \mathrm{C}(\mathrm{A})$ and $16.5^{\circ} \mathrm{C}(\mathrm{B})$. 


\section{LIST OF FIGURES}

FIGURE

A Schematic Diagram of the Apparatus Used to Determine the Presence of an Attracter Substance in Thelepus.

A Model of the Respiratory Chamber Used to Measure Oxygen Consumption in Thelepus and Halosydna.

A Diagram of the Irrigation Chamber Used to Measure the Volume of Water Pumped by Thelepus in the Presence and Absence of Halosydna in a Tube.

A Double Log Graph of the Wet Body Weights of

Halosydna vs Thelepus from Original

Commensal Pair in the Intertidal.

A graph of $\log$ oxygen consumption $\left(\mathrm{mlO}_{2} / \mathrm{h}\right)$ us

Log Body Wet Weight (g) at $12.5^{\circ} \mathrm{C}$ and

$16.5^{\circ} \mathrm{C}$ and at a Salinity of $33.0 \%$

A Graph of Log Weight-Specific Oxygen Consumption $\left(\mathrm{mlO}_{2} / \mathrm{g} / \mathrm{h}\right)$ vs Log Body Wet Weight $(\mathrm{g})$ at

12.5 and $16.5^{\circ} \mathrm{C}$ and a Salinity of $33.0 \%$

A Graph of Oxygen Concentration (part/million)

vs time (h) of Individual Thelepus and

Halosydna in a Respiration Chamber. 


\section{INTRODUCTION}

For a number of years naturalists have been intrigued with the highly specific association between species called symbioses. The factors responsible for bringing two animals together and maintaining an intimate partnership have not been recognized until recent years with the advent of physiological and behavioral studies on social organisms of the hymenopterous society (Davenport 1955 for review).

Commensalism is one of several categories of symbioses in which the commensal generally derives physical shelter from the host, is nourished on foods that are associated with but not part of the host, and is not metabolically dependent on the host (Cheng, 1967). Davenport (1950) has pioneered physiological and behavioral studies on a group of polychaete worms in which commensalism is widely established; the polynoid family of scaleworms. This group is particularly interesting since commensal scaleworms vary greatly in their specificity to hosts.

Commensalism has been reported in the polychaete families Aphroditidae, Polynoidae, Amphinomidae, Hesionidae, Pilargidae, Nereidae, and Myzostomidae. Commensal polychaetes are associated sponges, crustaceans, asteroids, echinoids, ophiuroids, holothuroids, crinoids and enteropneusts (Clark, 1956; Dales, 1957).

Approximately two-thirds of all the polychaetes that have been reported as commensals belong to the polynoid family of scaleworms (C1ark, 1956; MacGinitie and MacGinitie, 1968). One of the most perplexing features of commensalism in the polynoids is that not only do they have a strong propensity to adopt a commensal existence, but approximately 
$75 \%$ of a11 polynoid-annelid partnerships reported are with the tubebuilding family, Terebellidae. The remaining $25 \%$ involve other tubebuilding species from the families Eunicidae, Chaetopteridae, Maldanidae and a mud burrowing species from the family Nereidae (see C1ark, 1956 for listing).

Early physiological experiments on polynold-echinoderm partnerships and others (Davenport, 1950; Davenport and Hickok, 1951, 1957; Davenport, 1953a, b; Davenport, et a1., 1960; Barte1 and Davenport, 1956; Hickok and Davenport, 1957) have revealed that some commensals are attracted by a diffusible chemical produced by their hosts, termed a host factor. However, difficulty was encountered in demonstrating a host factor in some polynoid-terebellid associations (Davenport, 1953b). The common scaleworm, Halosydna brevisetosa, did not respond to the presence of its terebellid hosts, Neoamphitrite robusta (Johnson) (=Amphitrite robusta), at any distance, but did respond to physical contact with this host (Davenport and Hickok, 1951). However, identical physiological tests have not been performed with this commensal on another terebellid host, Thelepus crispus.

That chemical factors were not responsible for attraction in several adult partnerships need not necessarily mean that they were not important during some stage of development. Evidence from early observations (Davenport and Hickok, 1951; Pettibone, 1947, 1953) indicated that colonization of $\underline{T}$. crispus by its commensal $\underline{H}$. brevisetosa may be initiated during the early stages of their development and that both worms may continue their growth in the same tube. No studies have been made of this possibility. 
The effects of size upon the metabolism of annelids have been well documented (Dales, 1961a, b; Mangum, 1963; Sander, 1973). As in other marine poikilotherms, the total oxygen consumption (ml $0_{2} /$ animal/h) of individuals in the same species is found to be higher in larger animals, but the metabolic rate $\left(\mathrm{ml} 0_{2} / \mathrm{g} / \mathrm{h}\right.$ ) of smaller adults exceeds that of the larger. Generally, the metabolic rate varies with body size (Prosser, 1973).

The activity patterns and metabolic rates among marine annelids have been demonstrated to vary directly with oxygen tension (Dales et al., 1970; Hoffman and Mangum, 1970; Mangum, 1970; Mangum and Van Winkle, 1973; May 1972; Peterson and Johansen, 1969) and with temperature (Mangum, 1963, 1964; Mangum and Sassaman, 1969).

In addition, closely associated commensal annelids may depress each other's respiration rates. Evidence of an interspecific interaction in the respiration of two tubificid oligochaetes exists, in that the same individuals respire significantly less in a mixed culture than in separate culture (Brinkhurst et a1., 1972; Chua and Brinkhurst, 1973). At present, the respiratory interaction between two commensal marine annelids has not been investigated.

The general purpose of this study was to investigate the commensal relationship between the polynoid Halosydna brevisetosa Kinberg and its terebellid host Thelepus crispus Johnson. Included in this study are investigations concerned with detecting the presence of diffusible attractants from the host, which would enable recognition by its commensal. Further studies were made to elucidate the relationship between the sizes of these two annelids with respect to host colonization and their 
post-embryonic development together. Additional observations of hostcommensal behavior were conducted in the laboratory to better understand their physical and behavioral relationship within their tube. The final study consists of a detailed investigation to determine the relationship between host and commensal respiration and tube irrigation rates.

\section{Natural History}

Thelepus crispus Johnson is a tube-building terebellid polychaete worm which inhabits the rocky intertidal zone from the Alaskan Peninsula to southern California (Hartman, 1951). Large colonies to $T$. crispus are found building tubes under boulders and in narrow rock crevices below the $0.0 \mathrm{ft}$. water level. They have also been observed constructing tubes in empty shells of the rock-boring clam Penitella penita at Fossil Point near Charleston, Oregon. T. crispus can be distinguished by its bright pink body, long white tentacles, and red gills located at the anterior end (Barnes, 1968).

Tubes are constructed of coarse sand, pieces of shell and detritus which are collected by the long tentacles extending from the anterior end. Since tentacles are non-selective, all food and tube-building particles retrieved by the sticky tentacle epithelium are passed back along ciliated gutters towards the mouth (Barnes, 1968; Dales, 1970). Detritus accumulated at the base of each tentacle is then individually wiped over an upper lip bordering the mouth. Tube building occurs in the following manner: as the worm rotates it secretes a mucoid substance consisting of mucoprotein and mucopolysaccaride (Defretin, 1971) from special shield glands which is used to cement particles together to 
construct a sturdy cylindrical tube. Additional mucus layers are secreted establishing a smooth surface inside the tube through which the worm moves up and down (Dales, 1970).

Like many terebellids, $\underline{T}$. crispus maintains a flow of water in its tube across its highly vascularized gills by peristaltic action which produces swellings of its body wall which originate posteriorly on the worm (Dales, 1961b). There are also short periods of rest with no pumping, and on rare occasions, the peristaltic movement reverses direction, with pumping beginning at the anterior end. After the worm reverses in the tube during the process of defecation, it may remain in this position with its tail towards the opening for some hours without feeding. Irrigation continues in the same posterior to anterior direction. There is usually a single commensal, 트. brevisetosa, in each tube of $\underline{T}$. crispus.

Halosydna brevisetosa is one of the most common polynoids inhabitIng the same portion of the Pacific coast as its host, $\underline{T}$. crispus (Pettibone, 1953), but this species has been reported as far south as Peru (Hartman-Schröder, 1960). A free-living form of the same species, inhabiting the same general zone, can be distinguished from the commensal form by its light tan color and shorter length, which rarely exceeds one inch. The free-1iving form has been found as deep as 298 fathoms (Pettibone, 1953).

Polynoids are voracious raptorial feeders as is evidenced by the four chitinous jaws located on the end of a protrudable pharynx (Ricketts, Calvin and Hedgpeth, 1968).

Polynoid annelids are commonly called scaleworms because of the double row of scales or elytra down their dorsal side. The elytra 
serve several major functions. Eggs leave the body cavity during the spring and summer months (MacGinitie, 1939 from Pettibone, 1953) and are attached by mucus secretions to each other beneath the scales. Elytra also function as respiratory structures by directing oxygenated water currents posteriorly across the dorsal epidermis of the scaleworm. The counter-current flow of coelomic fluid (by ciliary action) facilitates the transfer of dissolved oxygen across the thin epidermis (LwebugaMukasa, 1971).

The commensal form of $\underline{H}$. brevisetosa has a broad spectrum of hosts (Table 1), some of which have other polynoid commensals (Clark, 1956; MacGinitie and MacGinitie, 1968; Pettibone, 1953). 
TABLE 1

A SUMMARY OF INVERTEBRATES REPORTED AS HOSTS TO H. BREVISETOSA

HOSTS

Neoamphitrite robusta (Johnson)

Pista pacifica (Berkeley)

P. elongata Moore

Thelepus crispus Johnson

Halosydna brevisetosa

Kinberg

Loimia montagui (Grube)

*Platynereis anassizi (Ehlers)

+Paguristes bakeri
OTHER COMMENSALS

Harmothoë Imbricata ( $L_{i}$ )

Polyeunoa tuta (Grube)

Arctonaë vittata (Grube) Harmothoë imbricata (L.) Polyeunoa tuta (Grube)

Artonoë pulchra (Johnson)

Summary of invertebrates reported as hosts to $\underline{H}$. brevisetosa. Other polynold commensals are found with the same hosts. All hosts are from the family Terebellidae, except * Family Nereidae, and + Tribe Anomura. Halosydna were always found living in the umbilicus of the moonsnail shell Polinices lewisii

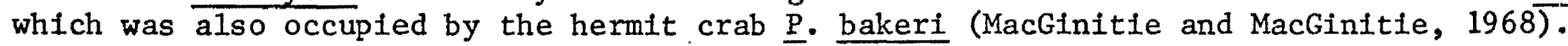

Halosydna and related polynoids are assoctated with polychaete worms with leathery or sandy tubes; no commensal polynoids as yet have been found with serpulid polychaetes with tubes of calcium carbonate (MacGinitie and MacGinitie, 1968). 


\section{METHODS AND MATERIALS}

\section{Collection and Culturing}

Specimens were collected in the rocky intertidal at low tides during the months of June, July, October, November and December of 1973, and January of 1974 at Seal Rock State Park, Oregon. Care was taken to obtain animals in their original host-commensal association.

Collections were chilled and immediately transported to the $1 \mathrm{ab}$ and placed in pairs as collected in culture dishes of sea water at 8.5$10^{\circ} \mathrm{C}$. Except where noted, all sea water used for culturing and experimentation was obtained, filtered and UV-light treated from the Oregon State University Marine Science Center holding tanks. After removing all tube material, the original commensal pairs were placed in culture dishes in sea water containing $0.06 \%$ penicillin-G and $0.01 \%$ streptomycin sulfate. The sea water solution was changed every two to three days.

Host-Commensal Weight Relationship

Host-commensal pairs from the June and July collections were blotted dry and weighed. A logarithmic plot was made from the wet weights with $\underline{T}$. crispus recorded on the abscissa and $\underline{H}$. brevisetosa on the ordinate. The slope (a) and y-intercept (b) for the combined data of the thirty-six pairs of specimens was calculated using the formula, $Y=a x^{b}$ (Appendix II). The correlation coefficient ( $r$ ) for the data calculated, and tested for significance by the t-test.

\section{Test for Physiological Attractants}

The apparatus, (Figure 1) used to test for the presence of an 


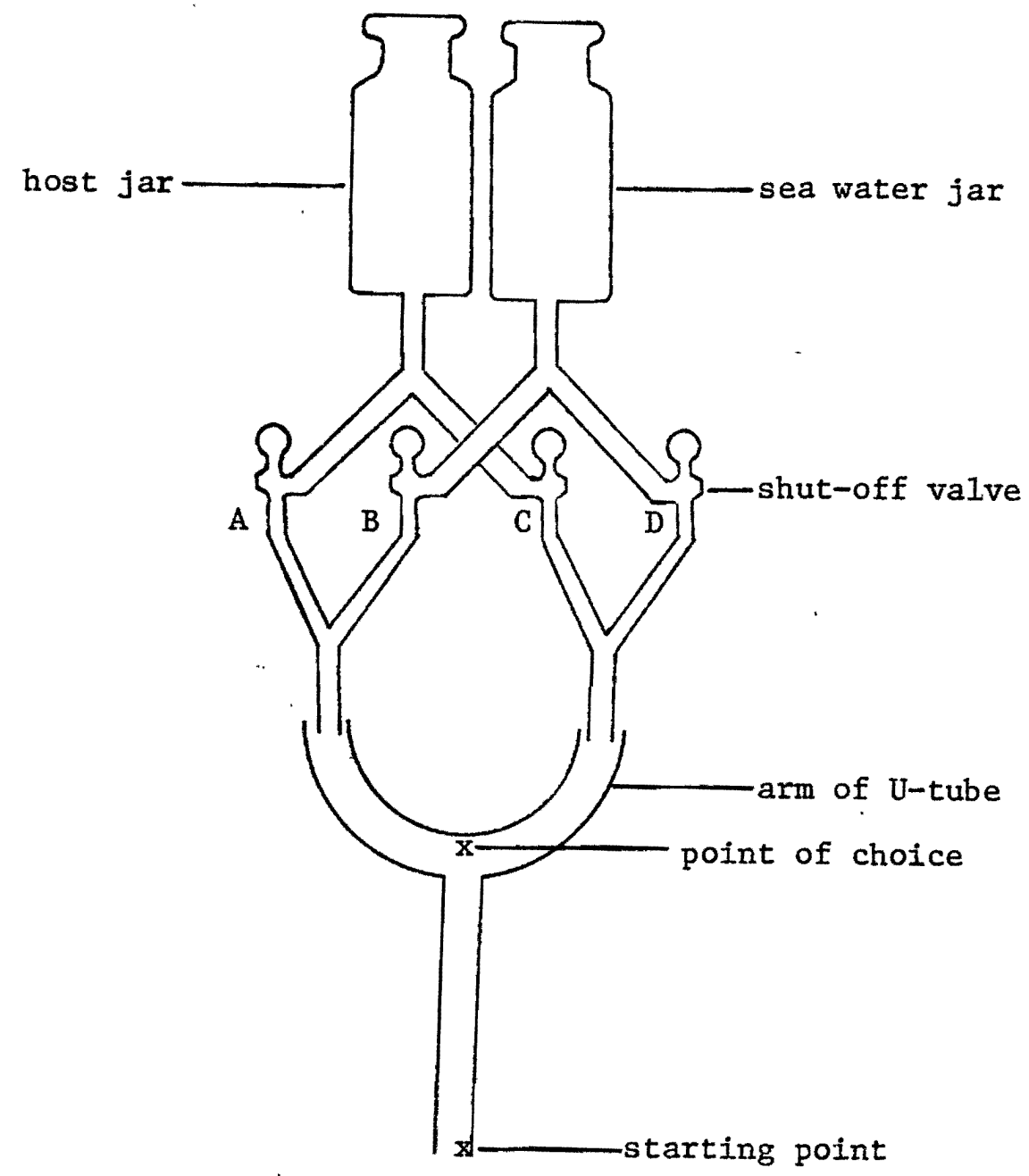

F1gure 1. A schematic diagram of the apparatus used to determine the presence of an attractor substance in Thelepus, indicates the starting point where Halosydna specimens enter the U-tube and the point of choice at which the commensal must turn up either arm of the U-tube. Shut-off valves (A\&D) are open and $B \& C$ closed, alternately between each run. The U-tube was darkened with black tape and a flap left at the point of choice for observation. 
attractor substance emitted by Thelepus was a modification of the apparatus described by Davenport (1950), Gerber and Stout (1969), and Webster (1969). Instead of the Y-tube used by these authors, a standard U-shaped glass tube was substituted. This was done to insure that the angle between the arms was greater than ninety degrees, in the hope that this would minimize the occurrence of a test commensal following the contour of the stem into one of the arms.

Two four-liter aspirator bottles (Figure 1) were filled with sea water, which was continuously aerated. Tubing was hooked up in such a manner that sea water from either jar could be directed to flow continually through either arm via four plastic shut-off valves (Hykro, Holland). All experiments were carried out at $8 \cdot 5-10^{\circ} \mathrm{C}$. The U-tube was darkened with electrician's tape.

To prevent water from mixing or backing up the other arm of the U-tube at the point of choice (Figure 1), the rate of flow in both arms had to be regulated. Injections of a $3 \%$ solution of Grenacher's borax carmine (Davenport, 1950) were used to determine the rate of flow which was maintained at approximately two drops/sec. from each arm.

Thirteen to fifteen Thelepus were placed in the host jar and allowed to stay from one to twenty-two hours prior to each experiment. An experiment consisted of a series of individual trials using a total of four to thirteen specimens of $\mathrm{H}$. brevisetosa, chosen at random from isolated cultures.

Commensals introduced to the stem of the darkened U-tube were required to make a choice between water flowing from the host $j a r(t)$ or the sea water jar $(-)$. Failures were noted for scaleworms not entering 
either arm within ten minutes. The host's sea water was used once for each experiment, then changed. After flushing all tubing with $500 \mathrm{mls}$. of sea water between consecutive trials, water from the host and sea water jars was switched to opposite arms of the U-tube with the use of the shut-off valves.

\section{Observation of Behavior}

Ten pairs of specimens of $\underline{T}$. crispus and $\underline{H}$. brevisetosa were placed in separate culture dishes filled with sea water at $8.5-10^{\circ} \mathrm{C}$. The bottom of the dishes was covered with sand obtained from the collection site, which had previcusly been washed several times and dessicated in a drying oven for three days at $60^{\circ} \mathrm{C}$ then rewetted with sea water. Terebellids were allowed to rebuild tubes along the bottom and sides of the culture dishes, utilizing the glass surfaces as one side of their tubes in their construction. This provided a clear view of activity within the tubes at any time.

\section{Oxygen consumption and size}

I. crispus and its commensal $\underline{\mathrm{H}}$. brevisetosa were induced to occupy various diameters of tygon tubing selected to approximate the size of their natural tubes. Five to ten days was given each terebellid to reconstruct a mucus lining.

Oxygen consumption was measured with a YSI model $5420 \mathrm{~A}$ self-stirring B.0.D. oxygen probe, and monitored with a YSI model 54 meter and a chart recorder. A Lucite respiratory chamber (Figure 2) of $130 \mathrm{mls}$. volume, was constructed to contain the oxygen probe and sample specimens. Experiments were carrled out using single host-commensal pairs 


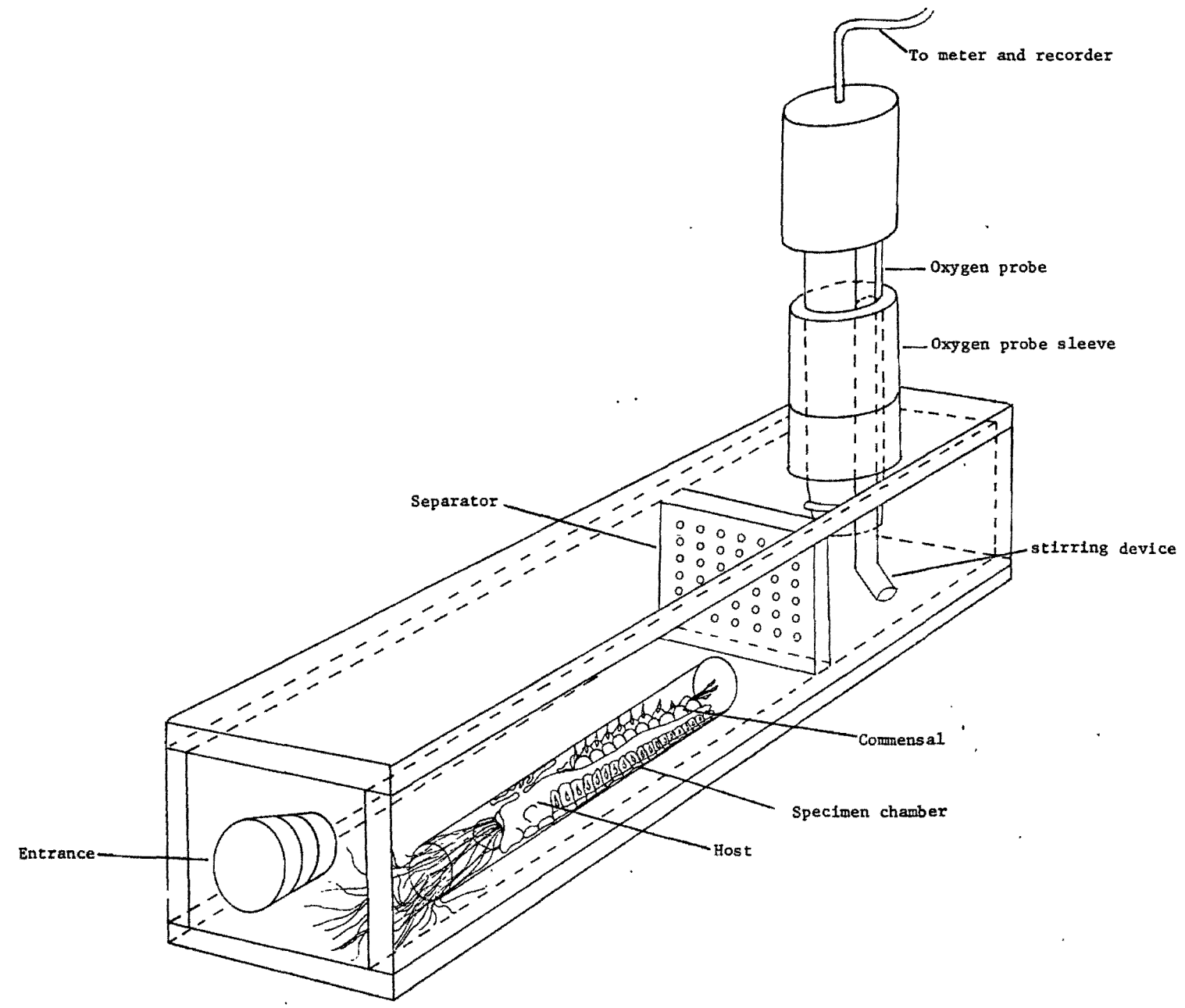

Figure 2. A model of the respiratory chamber used to measure oxygen consumption in Thelepus and Halosydna.

Spectmens acclimated to tygon tubing were inserted into the chamber through a hole at one end which was fitted with a rubber stopper. The separator prevents Thelepus tentacles from interfering with the stirring device attached to the oxygen probe, which fitted tightly into a frosted plastic sleeve. 
at 12.5 and $16.5^{\circ} \mathrm{C}$, which was approximately the average mean $\left(12.0^{\circ} \mathrm{C}\right)$ and highest mean $\left(15.85^{\circ} \mathrm{C}\right)$ inshore sea surface temperature, respectively, reported nearest the collecting area (Gonor et al., 1970). Each experiment contained four consecutive trials; host alone, host and commensal and commensal alone and tygon tubing with mucus linings, each lasting from 40-60 minutes. The last reading was subtracted from the others to compensate for oxygen consumption by the probe and tube material. The chamber was washed between experiments to avoid algae growth. The dissolved oxygen in the sea water at the beginning of each trial was adjusted to saturation values for each temperature and for the salinity, according to Green and Carritt (1967). The temperature in the chamber was regulated by a water bath and the salinity was periodically monitored (Barnes, 1959) and kept at 32.9-33.2\% $\%$ \pm \% $/ 00$. Due to seasonal changes in salinity of sea water, artificial sea water (Instant Ocean, Aquarium Systems, Inc., Wickliffe, Ohio) was substituted in some of these experiments. Animals were acclimated for at least flve days within $7^{\circ} \mathrm{C}$ of experimental temperatures. Acclimation periods in the apparatus, just prior to experiments, lasted from 1-3 hours.

\section{Irrigation Rates of Commensal Pairs}

A flow meter (Figure 3) was designed to measure the volume of sea water moved by $\underline{T}$. crispus through each tube, both in the presence and absence of its commensal. Tygon tubing, occupied by host specimens, was fitted over plastic connectors between the reservoirs. A siphon from a two liter source fed sea water into the rear reservoir the level of which was kept constant with a platform jack located under the water 


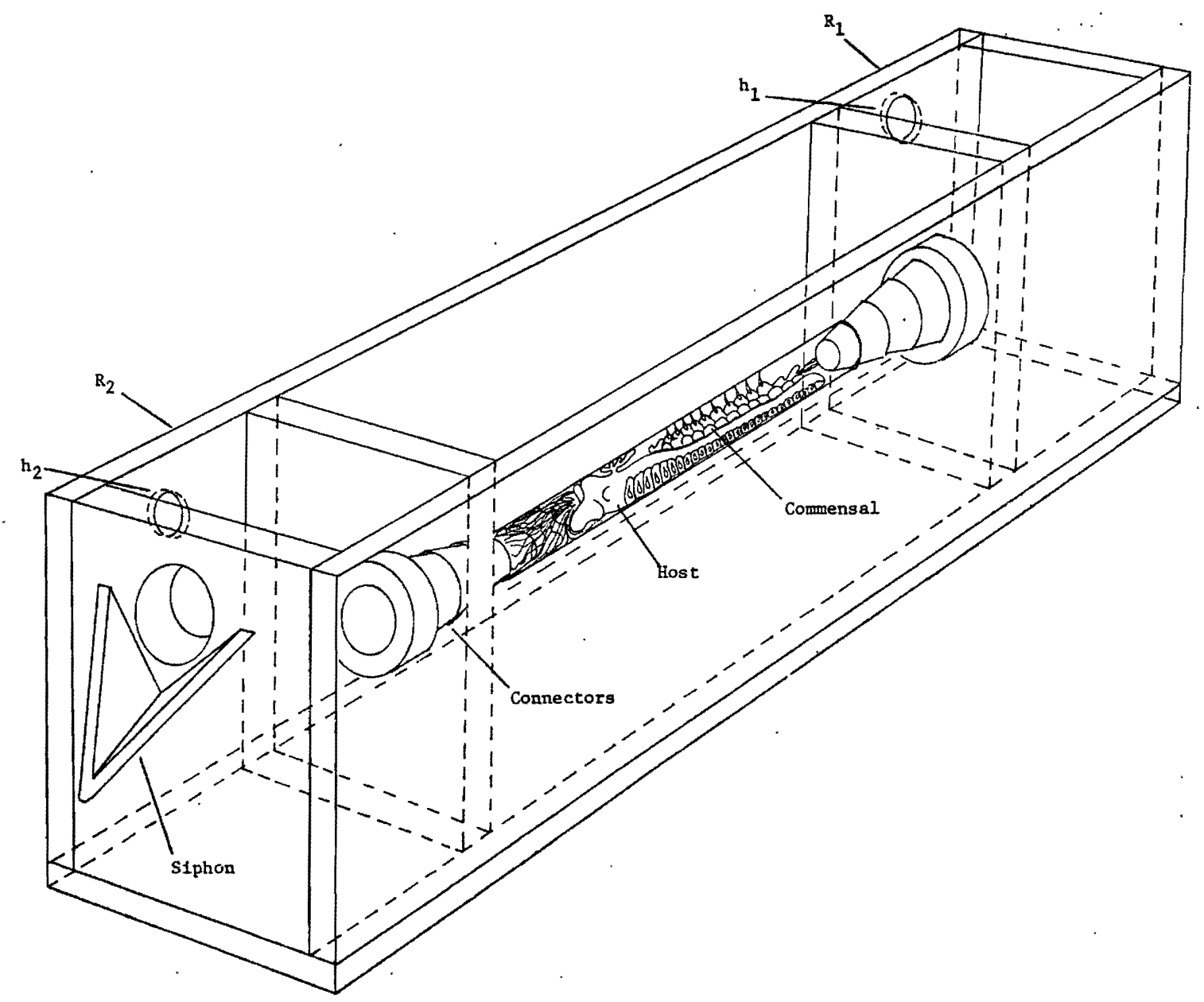

F1gure 3. A diagram of the 1rrigation chamber used to measure the volume of water pumped by Thelepus in the presence and absence of Halosydna in a tube.

This diagram represents an irrigation chamber which measures the volume of water pumped by a specimen of Thelepus from one reservoir $\left(R_{1}\right)$ to the other $\left(R_{2}\right)$. Tubing from a water source (not pictured) provides a constant reservoir $\left(R_{1}\right)$. Two holes on the sides $\left(h_{1}\right.$ and $h_{2}$ ) prevent water leveis from overflowing. A siphon directe displaced water from a thin-lip hole into a graduated cylinder. 
bath system. Before specimen tubes were connected, the water level in the chamber was adjusted to $2.0 \mathrm{~mm}$ : below the spout hole so the terebellid would be pumping against a slight back pressure as water overflowed. The hole cut behind the spout provided a constant water flow with negligible surface tension. Overflow volumes were read at consecutive ten minute intervals after the organisms had acclimated from 2-5 hours in the chamber at each experimental temperature. Commensals were then introduced into the apparatus by allowing them to crawl through the connectors from the forward reservoir. 


\section{RESULTS}

Test for Physiological Attractants

It is clear from the literature that some commensal worms are attracted to their hosts from a distance by a chemical attractant, while others depend on detection by physical contact when a host is randomly encountered (Davenport, 1955). With the aid of a U-tube choice apparatus, the effects of a putative dispersable chemical from a number of Thelepus on commensal Halosydna were tested.

In the 62 trials performed (Table II) there was no evidence of an attractive substance in the sea water flowing from the reservoir which had contained a number of host Thelepus. In each set of trials, the movement of a commensal into either arm of the U-shaped tube constituted a completed run (Figure 1). A failure was recorded if the commensal did not move into either arm of the U-tube within ten minutes.

Out of 50 completed runs, only $54 \%$ of the Halosydna (27) moved into the arm containing water from its host. Davenport and Hickok (1951) observed that only $56 \%$ of the Halosydna chose water from the arm of a Y-tube apparatus leading from the terebellid host Neoamphitrite robusta.

It might be expected that the host factor from Thelepus increases in concentration with the time spent in the container. However, there is only one set of trials ( $14 \mathrm{hrs}$ in Table II) where the results are significantly different from random selection.

Efforts were made to keep environmental conditions compatible for specimens throughout experimentation. Except for a few specimens, no two commensals were used twice in the same experiment in an effort to prevent overhandling. Since Halosydna, like many polynoids, are negatively phototactic (Dales, 1970), all specimens were kept in the dark 
before and during trials. Experiments lasting longer than 22 hours were terminated due to fouling of the water containing host worms.

The reason that no failures occurred in the 20 and 22 hour experiments is not certain, but may be due to commensal acclimation to the repeated experimentation.

In a similar experiment, Davenport and Hickok (1957) could find no evidence of a chemotropic response in Halosydna to another terebellid host; N. robusta. Likewise, Davenport (1953a) obtained similar results for other scaleworms commensal with terebellids, and suggested that these worms may identify their terebellid host (by specific chemicals) after fortuitous physical contact with the host.

Host-commensal Weight Relationship

It was noted in the intertidal that each Thelepus tube contained a single Halosydna which was roughly proportional in size to its host. Small commensals were never found with large hosts. When this data was quantifled a specific size relationship between the two worms was revealed.

In Figure 4, the body wet weight (g) of Thelepus is plotted against

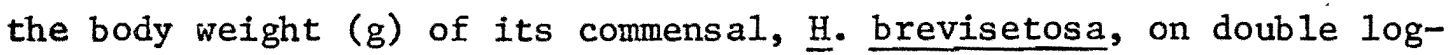
arithmic paper and the regression line is fitted to the equation, $Y=$ a $\mathrm{X}^{\mathrm{b}}$ (Appendix II). Each point on the graph represents a single hostcommensal pair as collected from individual tubes in the intertidal.

The high correlation coefficient $(r=0.9408)$ is statistically significant $(\operatorname{Pr}<0.001)$ showing that a direct size relationship between Thelepus and Halosydna exists. Since the slope $(b=0.9167)$ of the regression line is close to 1.0 , the wet weight of the host is nearly 
SIGNIFICANT OF HOST FACTOR IN T. CRISPUS ATTRACTING COMMENSAL $\underline{\mathrm{H}}$. BREVISETOSA

\begin{tabular}{|c|c|c|c|c|c|c|c|c|}
\hline \multirow[b]{2}{*}{ BREAKDOWN OF RESULTS } & \multicolumn{8}{|c|}{$\begin{array}{l}\text { Time (hrs.) in which Thelepus stayed in } \\
\text { sea water prior to each experiment }\end{array}$} \\
\hline & 1 & 12 & 14 & 16 & 18 & 20 & 22 & Total \\
\hline No. of Halosydna used in each experiment & $13 *$ & 4 & 9 & 7 & 8 & $8 *$ & $8 *$ & 57 \\
\hline No. of Trials & 16 & 4 & 9 & 7 & 8 & 9 & 9 & 62 \\
\hline Total of completed runs & 11 & 2 & 7 & 6 & 6 & 9 & 9 & 50 \\
\hline No. of runs into Thelepus arm ( + ) & 6 & 1 & 5 & 2 & 4 & 6 & 3 & 27 \\
\hline No. of runs into sea water arm $(-)$ & 5 & 1 & 2 & 4 & 2 & 3 & 6 & 23 \\
\hline No. of fallures to choose an arm & 5 & 2 & 2 & 1 & 2 & 0 & 0 & 12 \\
\hline Runs into Thelepus arm (\% of total completed runs) & 55 & 50 & 71 & 33 & 66 & 66 & 33 & $54 \%$ \\
\hline Fallures (\% of total no. of trials) & 31 & 50 & 22 & 14 & 25 & 0 & 0 & $19 \%$ \\
\hline
\end{tabular}

* Some Halosydna specimens used more than once per trial (experiment).

A completed run constitutes the movement of a single commensal (Halosydna) into either arm of the U-tube.

A failure is recorded if the commensal does not move into either arm of the U-tube within 10 minutes. 
proportional to that of its commensal.

One point (insert in Figure 4) consists of a small host (30 mg) and its commensal (10 mg). The wet weight of this host (X) was inserted into the equation, $Y=a X^{b}$ (using the calculated values of $a$ and $b$; (Table III) and the estimated value for the commensal weight (Y) is $8.879 \mathrm{mg}$. This is close to the actual $10 \mathrm{mg}$ value stated above (computations in Appendix III). The regression line calculated from all 36 commensal pairs (Figure 4) is not significantly different from a line derived by omitting only the smallest point, as can be seen from the data in Table III. 


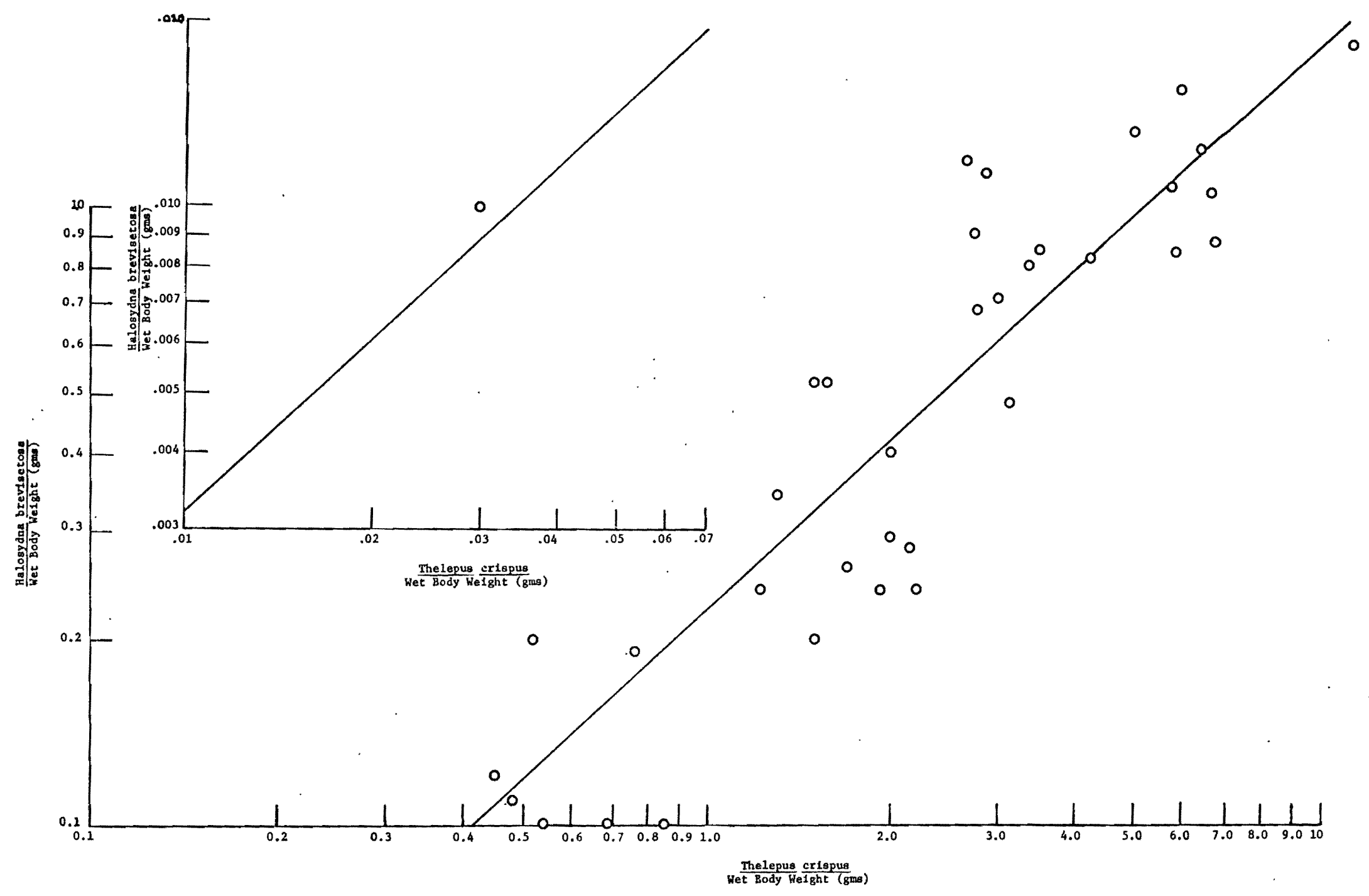

Pigure 4. A double log graph of the wet body weighta of Halogydna vs Thelepus from original cosmensal pair in the intertidal. 
TABLE III

REGRESSION ANALYSIS OF T. CRISPUS

AND $\underline{\text { H. }}$ BREVISETOSA WET WEIGHTS

$\operatorname{Pr}$

\section{Logarithmic}

$\mathrm{Y}=\mathrm{a} \mathrm{X}^{\mathrm{b}} ; 36$ pairs

$\log Y=\log 0.2210+0.9167 \log X$

0.9408

$(P r<0.001)$

$\mathrm{Y}=\underline{\mathrm{a}} \mathrm{X}^{\mathfrak{b}} ; 35$ pairs

$\log Y=\log 0.2200+0.9132 \log X$

0.9171

$(\operatorname{Pr}<0.001)$

* Smallest pair ommitted from calculation of regression line

$r$ = Correlation coefficient

$\operatorname{Pr}=$ Probability (t-test) 
This data suggests that commensalism in Thelepus and Halosydna may begin at a very early stage of post-embryonic development. Pettibone (1947, 1953) reports a case of two small commensal Halosydna (7 mm and $15 \mathrm{~mm}$ long) found in the tube of a small Thelepus ( $30 \mathrm{~mm}$ 1ong) in the San Juan Archipelago. Both of these commensals had only 14 of the 18 scales normally found in mature adults, suggesting that host colonization may have occurred during post-embryonic development.

The wet weights in this data also include the gut contents of each worm since no more than twelve hours had elapsed between their collection and weighing. The presence of gamete development within the coelomic cavity of either worm would also influence the data, but no evidence of gamete production was observed during these late June and July collections.

According to Daly (1972), no detailed comparison of the mechanisms by which commensal pairs are formed and maintained in different species is yet possible. Little is known about the breeding biology of Halosydna or other polynoids (Daly, 1972) except that Halosydna has been observed carrying eggs and sperm from September through Febrary during which part of this study was conducted. MacGinitie (1939 from Pettibone 1947, 1953) reported gametes maturing in Halosydna during the spring and summer months at Elkhorn Slough, California. Specimens of Thelepus from early December collections secreted long strands of mucus sacs filled with bright yellow eggs, but no evidence of sperm production was observed.

\section{Host-Commens al Behavior}

The manner in which specimens of Thelepus built new tubes along 
the walls of glass dishes provided an unobstructed view of tube construction and host-commensal behavior within each tube. The behavior of Halosydna outside of the host tube was also observed.

Tube building in Thelepus was observed to be much the same as reported for other terebellids (Dales, 1955; Brown and E1lis, 1972). The rates of tube construction were notably faster at night than during the day. Another terebellid, Neoamphitrite robusta, proceeded significantly $(8<0.001)$ faster at night $(\overline{\mathrm{x}} 0.51 \pm .04 \mathrm{~cm} / \mathrm{hr})$ than during the day $(\overline{\mathrm{x}} 0.03 \pm .02 \mathrm{~cm} / \mathrm{hr}$ ) (Brown and E1lis, 1972). Thelepus constructed new tubes sufficient to cover the body within 12-48 hours.

Halosydna, separated from the hosts during tube re-building, were added to dishes containing their original hosts to observe their behavior. Without exception, commensals moved randomly until head contact with host tentacles was established. After contact, each scaleworm followed the tentacles down to the anterior end of the host's tube. Identical behavior was observed by Orton and Smith (1935) using another polynoid-terebellid pair from the English coast, and the same hostlocation procedure for Halosydna was reported with an alternate terebellid host, $\underline{N}$. robusta (Davenport and Hickok, 1951), although the hosts in this case were tubeless.

When available specimens of free-living Halosydna were placed in dishes containing Thelepus in their tubes. In every case no attempt was made to find or associate with the host, even when physical contact occurred. Similarly, Hickok and Davenport (1957) compared the behavior of the scaleworm Podarke pugettensis, which is commensal with the starfish Luidia foliolata, with free-living scaleworms of the same species 
and from the same geographic area. The commensal individuals quickly found the host while the free-living ones did not.

Commensal behavior of Halosydna was viewed through the portion of the transparent mucus secretion (Defretin, 1971) which the host had affixed to the glass walls of culture dishes. The unattached portion of the tube was reinforced with several layers of sand. Each Halosydna, after entering the host tube, eventually came to rest against the host's body wall with its ventral side against the tube lining. All hosts and their commensals were in place and facing in opposite directions in the tube within two to six hours after the commensals were introduced. Thelepus maintained a posterior-anterior flow of water through their tubes using peristaltic movements of the body wall. Without exception, commensals were positioned so that their anterior ends were directed into the oncoming water flow produced by its host. When commensal pairs were placed together, prior to tube reconstruction, Halosydna quickly located and coiled around the host's tubeless body, and a new tube was built over both animals. There were no apparent differences in the tube or the arrangement of the worms when compared to pairs established after tube construction. Although tube construction continued until the tubes were several times longer than their hosts, the commensals remained within the zone of peristaltic movement along the host's dorsal body wall. It was also noted several times that soon after Thelepus reversed body direction in their tubes in the process of defecation, their commensals also turned around. In six experiments Halosydna were introduced into the posterior end of their original host tubes. Within an hour the scaleworms had turned around and settled into their characteristic 
postion relative to the host.

Halosydna, as other scaleworms (Segrove, 1938), has the ability to move water over its body by the action of epidermal cilia. IwebugaMukasa.(1970) has demonstrated intense currents of water directed posteriorly by ciliary tracts located along the dorsal body surface and parapodial lobes of Halosydna. The overlapping elytra (or scales) are shaped so as to funnel this incoming flow posteriorly, over a thin dorsal epidermis. Coelomic circulation within the segments was found to run counter to the external flow of water, which would make a counter current system possible (Lwebuga-Mukasa, 1970). The water-directing action of the elytra appeared to Lwebuga-Mukasa (1970) to be enhanced rather than diminished when the animals occupied narrow sheltered spaces under rocks or shells, or inside worm tubes. The area between the host body wall and the tube lining may provide a similar environment for commensal Halosydna. Presumably, Halosydna also take advantage of the flow of water produced by its host, in that both annelids were positioned so as to produce water currents in the same direction. Halosydna's physical orientation with respect to the current in the tube was tested in the absence of its host in a ventilation chamber (Figure 3). A Halosydna specimen was introduced three separate times to each end of the tube. A current was created in the tube for 1 hour by increasing the volume in the rear reservoir of the chamber $1 \mathrm{~cm}$ above the forward reservoir. Two specimens were tested separately in this experiment. Halosydna that were already facing into the current did not change their orientation after 1 hour. However, in cases where Halosydna specimens were not directed into the current, they reversed their body 
orientation so that their anterior ends were facing into the oncoming current.

Additional observations revealed no apparent signs of injury to either hosts or commensals as a result of their association. Periodic checks at night revealed several Halosydna extended half way out of the anterior end of the host tubes. They were presumed to be foraging for food but were able to hastily retreat inside the tube when disturbed.

\section{Oxygen consumption vs body weight}

In this experiment, the rate of oxygen consumption was measured for Thelepus and Halosydna in the same tube and in separate tube cultures. Oxygen consumption was measured in this sequence: Thelepus alone; Thelepus and Halosydna; Halosydna alone. Then the oxygen consumed by the tube material and oxygen probe was measured and subtracted from each rate.

In Figures 5 and 6 , the regression lines represent two types of oxygen consumption rates ( $\log \mathrm{ml} \mathrm{O}_{2} / \mathrm{hr}$ and $\log \mathrm{ml} \mathrm{O}_{2} / \mathrm{g} / \mathrm{h}$, respectively) plotted against the Log body wet weight for Thelepus and Halosydna, at two temperatures $\left(12.5^{\circ} \mathrm{C}\right.$ and $\left.16.5^{\circ} \mathrm{C}\right)$. Gonor and his associates (1970) reported that the highest and lowest inshore sea surface temperature recorded daily at Agate Beach, Oregon for three years (October 1967 to November 1970 ) ranged from $18.3^{\circ} \mathrm{C}$ to $6.0^{\circ} \mathrm{C} .12 .5^{\circ} \mathrm{C}$ was chosen for one experimental temperature, $16.5^{\circ} \mathrm{C}$, borders on the highest 15 day mean $\left(15.85^{\circ} \mathrm{C}\right)$ over the same three year period.

For convenience, an individual culture is defined as a specimen of either Thelepus or Halosydna acclimated to tygon tubing. Tubing con- 
taining a host-commensal pair constitutes a mixed culture. Therefore, the three regression lines for each temperature indicate the rate of oxygen consumption for individual or mixed cultures within the respiratory chamber. The regression lines express oxygen consumption of the annelids as a power function of body size (Appendix II).

Statistical analysis presented in Table IV and V and examination of Figures 5 and 6 reveals that Thelepus and Halosydna increase oxygen consumption with increasing size (Figure 5), but that small individuals of both species consume oxygen at a faster rate per unit weight than do larger individuals of the same species (Figure 6). The correlation coefficient $(r)$ of each regression line in Figure 5 is significantly different from zero $(P<.0 .01$ to $P<0.001$ in Table IV), indicating that there is indeed a high degree of correlation between the wet body weight of these worms and their rate of oxygen uptake. The regression lines indicating weight-specific oxygen consumption (ml $0_{2} / \mathrm{g} / \mathrm{h}$ ), in Figure 6, also exhibits coefficients ( $r$ ) that are statistically significant $(\mathrm{P}<0.05$ to $\mathrm{P}<0.001$ in $T a b 1 e \mathrm{~V})$, but to a lesser degree than those values given for Figure 5 .

A statistical comparison of the slopes of several regression lines in Figures 5 and 6 , as we11 as the distance between the lines, are tested by covariant analysis (Appendix II). The regression lines representing Thelepus in individual tube cultures and Thelepus and Halosydna in mixed tube cultures are compared in Figures 5 and 6 at each temperature. The slopes of the regression lines tested are not significantly different from each other ( $F-1$ in Table IV and V), which indicates that the lines represent parallel rates of oxygen consumption. The distance between 
TABLE IV

COVARIANT ANALYSIS OF OXYGEN CONSUMPTION (ML $0_{2} / \mathrm{H}$ ) AS A FUNCTION OF WET BODY WEIGHT IN THELEPUS AND FAIOSYDNA USING AIR SATURATED SEA WATER AT $12.5^{\circ} \mathrm{C}$ AND $16.5^{\circ} \mathrm{C}$ AND A SALINITY OF $33.0 \%$ (FOR FIGURE 5)

\begin{tabular}{|c|c|c|c|c|c|c|c|}
\hline $\begin{array}{c}\text { Species } \\
\text { Combination }\end{array}$ & $\left(\begin{array}{c}\mathrm{T} \\
\left({ }^{\circ} \mathrm{C}\right) \\
\end{array}\right.$ & $\mathrm{N}$ & $\mathrm{b}$ & $r$ & $\operatorname{Pr}$ & F-test & Pf \\
\hline $\mathrm{T}$ & 12.5 & 11 & 0.7432 & & $<0.001$ & (1) 1.39 & N.S. \\
\hline $\mathrm{T}+\mathrm{H}$ & & 11 & 0.6353 & 0.8855 & $<0.001$ & $(\mathrm{df}=1.18)$ & \\
\hline $\mathrm{H}$ & & 11 & 0.5067 & 0.7761 & $<0.01$ & $\begin{array}{l}(2) 0.543 \\
(\mathrm{df}=1.19)\end{array}$ & N.S. \\
\hline $\mathrm{T}$ & 16.5 & 14 & 0.7142 & 0.8363 & $<0.001$ & (1) 0.909 & N.S. \\
\hline $\mathrm{T}+\mathrm{H}$ & & 14 & 0.6916 & 0.8191 & $<0.001$ & $(\mathrm{df}=1.24)$ & \\
\hline H & & 14 & 0.7092 & 0.9273 & $<0.001$ & $\begin{array}{l}\text { (2) } 3.15 \\
(\mathrm{df}=1.25)\end{array}$ & $<0.10$ \\
\hline
\end{tabular}

Cultures of species are represented by $\mathrm{T}$ (Thelepus), $\mathrm{H}$ (Halosydna) and $\mathrm{T}+\mathrm{H}$ (Thelepus + Halosydna). The number of specimens in each set of experiments is represented by $\mathrm{N}$; $\mathrm{b}$ indicates the slope of regression. Iines; I indicates correlation coefficient and $\mathrm{Pr}$ the significance of $\mathrm{r}$ being different from zero. The analysis of covariance (F-test) indicates the degree of difference between the slopes of $T$ and $T+H$ ( 1 ) and the level of the regression lines of $\mathrm{T}$ and $\mathrm{T}+\mathrm{H}$ on the ordinant (2) for each temperature. Degrees of freedom (df) are indicated for the two-tailed F-test and Pf indicates the test of significance of the differences among the regression lines. N.S. indicates not significant. 


\section{TABLE V}

COVARIANT ANALYSIS OF WEIGHT-SPECIFIC OXYGEN CONSUMPTION (ML $0_{2} / \mathrm{g} / \mathrm{h}$ ) AS A FUNCTION

OF WET BODY WEIGHT IN THELEPUS AND HALOSYDNA USING AIR SATURATED SEA WATER AT $12.5^{\circ} \mathrm{C}$ AND $16.5^{\circ} \mathrm{C}$ AND A SALINITY OF $33.0 \%$ (FOR FIGURE 6)

\begin{tabular}{|c|c|c|c|c|c|c|c|}
\hline $\begin{array}{l}\text { Species } \\
\text { Comb1nation }\end{array}$ & $\begin{array}{r}\mathrm{T} \\
\left({ }^{\circ} \mathrm{C}\right) \\
\end{array}$ & $\mathrm{N}$ & $\underline{b}$ & $r$ & $\mathrm{Pr}$ & F-test & Pf \\
\hline $\mathbf{T}$ & 12.5 & 11 & -0.2568 & -0.6128 & $<0.05$ & (I) 0.01 & \\
\hline $\mathrm{T}+\mathrm{H}$ & & 11 & -0.3647 & -0.7381 & $<0.01$ & $(\mathrm{df}=1.18)$ & \\
\hline $\mathrm{H}$ & & 11 & -0.4933 & -0.7678 & $<0.001$ & $\begin{array}{l}(2) 0.222 \\
(\mathrm{df}=1.19)\end{array}$ & N.S. \\
\hline $\mathrm{T}$ & 16.5 & 14 & -0.2858 & -0.5415 & $<0.05$ & (1) 0.216 & $\begin{array}{l}\text { N.S. } \\
\text { N.S. }\end{array}$ \\
\hline $\mathrm{T}+\mathrm{H}$ & & 14 & -0.3084 & -0.5371 & $<0.05$ & $(\mathrm{df}=1.24)$ & \\
\hline $\mathrm{H}$ & & 14 & -0.2908 & -0.7128 & $<0.01$ & $\begin{array}{l}\text { (2) } 2.09 \\
(\mathrm{df}=1.25)\end{array}$ & $<0.25$ \\
\hline
\end{tabular}

Cultures of species are represented by $\mathrm{T}$ (Thelepus), H (Halosydna) and $\mathrm{T}+\mathrm{H}$ (Thelepus + Halosydna). The number of specimens in each set of experiments is represented by $\mathrm{N}$; $\mathrm{b}$ indicates the slope of regression Iines; $r$ indicates correlation coefficient and $\operatorname{Pr}$ the significance of $r$ being different from zero. The analysis of covariance (F-test) indicates the degree of difference between the slopes of $T$ and $T+H$ ( 1 ) and the level of the regression lines of $\mathrm{T}$ and $\mathrm{T}+\mathrm{H}$ on the ordinant (2) for each temperature. Degrees of freedom (df) are indicated for the two-tailed F-test and Pf indicates the test of significance of the differences among the regressinn lines. N.S. indicates not significant. 


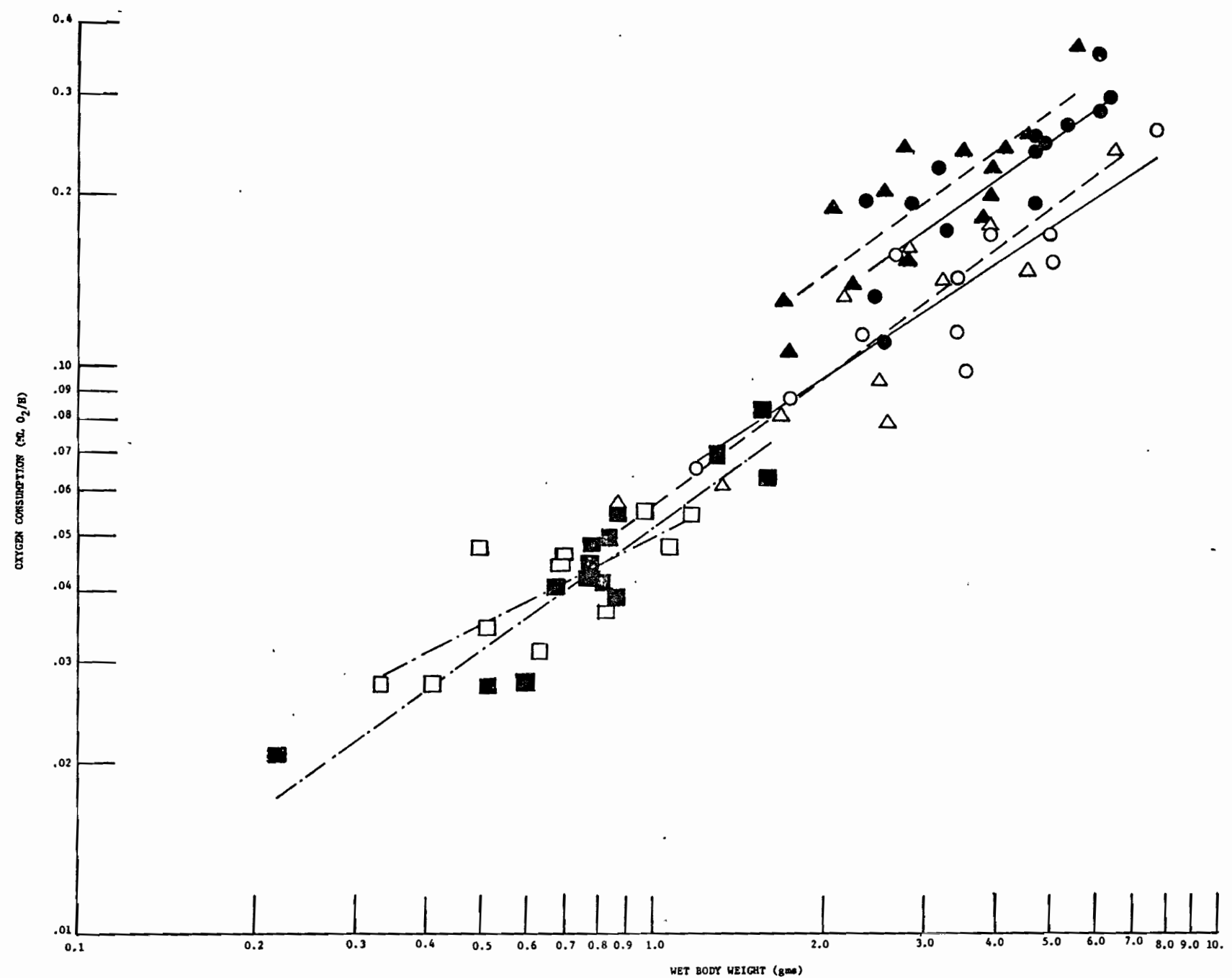

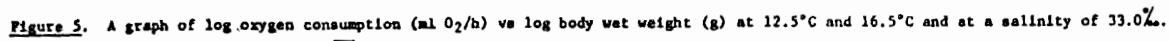

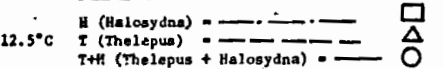

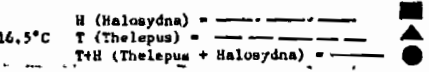




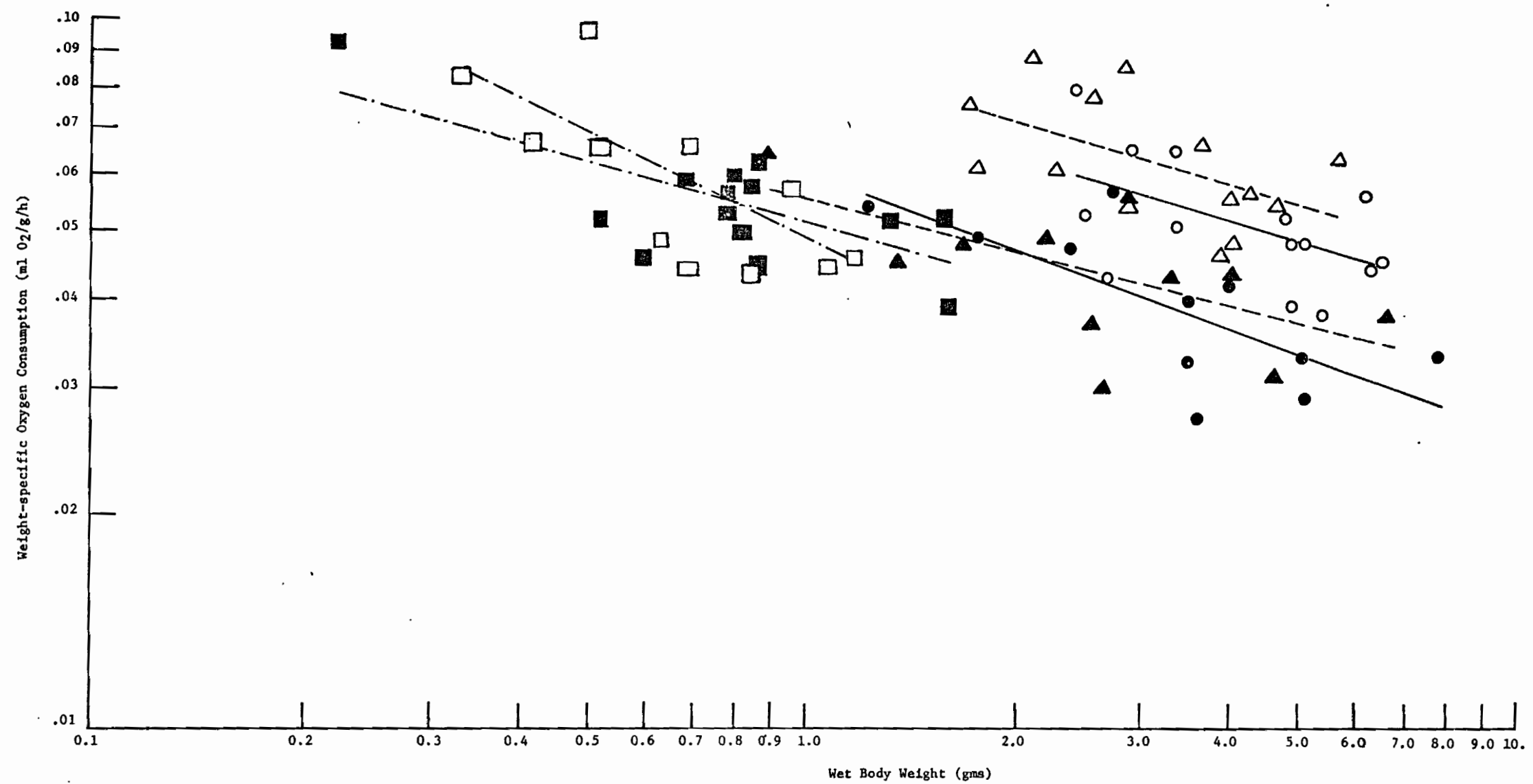

P1gure 6. A graph of $\log$ weight-spectf1c oxygen consumption (ml $\mathrm{O}_{2} / \mathrm{g} / \mathrm{h}$ ) vB $\log$ body wet weight (g) at 12.5 and $16.5^{\circ} \mathrm{C}$ and a sal1nity of $33.0^{\circ} \%$ o

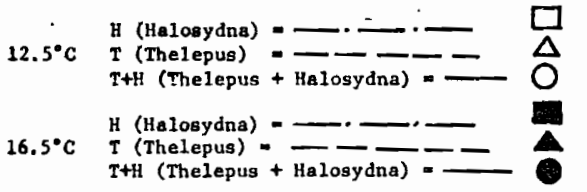


the same regression lines, representing individual and mixed cultures of worms, is not statistically. significant (F-2, Tables IV and V) at either $12.5^{\circ} \mathrm{C}$ or $16.5^{\circ} \mathrm{C}$ in Figures 5 and 6 . Therefore, the rate of oxygen consumption of individual Thelepus and mixed cultures of Thelepus and Halosydna can not be distinguished as separate lines, which is evidenced by the large number of overlapping points observed along the regression lines representing these cultures in Figure 5.

There are several instances at both temperatures in which the oxygen consumed by an individual host Thelepus is higher than that for the same host and its commensal in a mixed culture (Appendix I). By fitting all the individual points at $16.5^{\circ} \mathrm{C}$ to regression lines, by the method of least squares (Appendix II), it is observed that the hostcommensal rate of oxygen consumption is below that for individual hosts over the same weight range (Figure 5). However, in most of the data fitted to the regression lines, a given mixed culture of Thelepus and Halosydna respire more than the same host Thelepus in an individual culture.

Individual cultures of Halosydna have a very low absolute rate of oxygen uptake $\left(\mathrm{ml} \mathrm{O}_{2} / \mathrm{h}\right)$ compared with that of its host (Figure 5), but it consumes more oxygen per unit weight than Thelepus due to its small size (Figure 6). Therefore, Halosydna may not have a significant influence on the consumption of oxygen in a mixed culture with its host.

It is evident from Figure 7 that the oxygen consumption for individual Thelepus and Halosydna is clearly influenced by low oxygen concentrations in the water. For this reason the oxygen concentration for all the above experiments was never allowed to fall below $70 \%$ of the saturation 


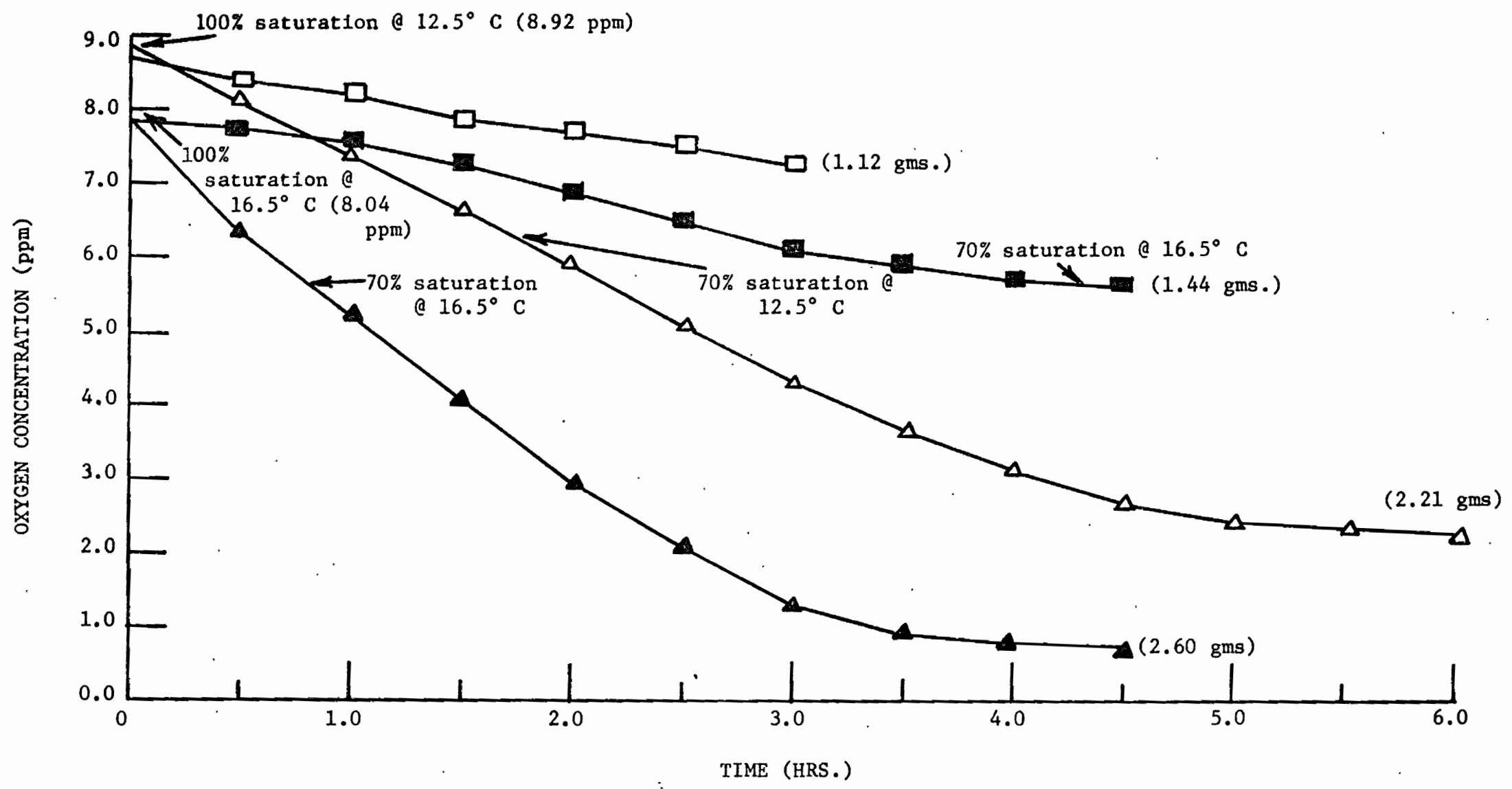

Figure 7. A graph of oxygen concentration (part/miliion) vs time (h) of individual Thelepus and Halosydna in a respiration chamber.

Reveals the depletion of oxygen by individual Thelepus (triangles) and Halosydna (squares) at $12.5^{\circ} \mathrm{C}$ (11ght symbols) and $16.5^{\circ} \mathrm{C}$ (dark symbols) as recorded at $1 / 2$ hour Intervals. The location of the $100 \%$ and $70 \%$ oxygen saturation values for each line is noted along with the wet body weight of each annelid tested. 
values for each temperature. At $12.5^{\circ} \mathrm{C}$, none of the annelids tested consumed more than $30 \%$ of the oxygen supply within one hour. The rate of oxygen uptake for a $2.21 \mathrm{~g}$ Thelepus at $12.5^{\circ} \mathrm{C}$ remains constant for more than two hours (Figure 7). However, at higher temperatures, Thelepus and Halosydna consume oxygen at a faster rate (Figure 5). The higher respiration rate combined with the lower oxygen saturation point at $16.5^{\circ} \mathrm{C}$ enabled a number of individual and mixed cultures to reach the $70 \%$ saturation point before an hour had elapsed. For example, a $2.6 \mathrm{~g}$ Thelepus depletes the oxygen concentration to $70 \%$ of saturation at $16.5^{\circ} \mathrm{C}$ in approximately 45 minutes (Figure 7). The rate of oxygen consumption is approximately constant during the first hour. Except for very large specimens, the rates determined in 45 minutes are acceptable. Consequently, the very large specimens (more than approximately $10 \mathrm{~g}$ ) were not used in this experiment. Halosydna never consumed more than $30 \%$ of the available oxygen during a one hour period.

Further examination of Figure 7 reveals that Thelepus specimens of similar wet weight $(2.21 \mathrm{~g}$ and $2.60 \mathrm{~g})$ discontinue their oxygen uptake at different levels of oxygen concentration depending on the water temperature. After $4 \frac{1}{2}$ hours, a $2.21 \mathrm{~g}$ Thelepus has consumed $70 \%$ of its available oxygen at $12.5^{\circ} \mathrm{C}$, and its rate of oxygen consumption is still declining. However, a $2.60 \mathrm{~g}$ worm at $16.5^{\circ} \mathrm{C}$ has consumed $91 \%$ of its oxygen supply and has discontinued its oxygen consumption. After 3 hours of respiration, a large specimen of Halosydna at $12.5^{\circ} \mathrm{C}$ still has $81 \%$ of its oxygen supp1y remaining and the other scaleworm has retained $76 \%$ of its oxygen at $16.5^{\circ} \mathrm{C}$. This represents the oxygen uptake of only a few specimens under reduced oxygen concentrations and many more tests 
are needed before any conclusions can be drawn. However, Figure 7 does reveal the large difference in the oxygen uptake between this host and commensal even when the Halosydna specimens are very large $(1.12 \mathrm{~g}$ and $1.44 \mathrm{~g})$.

Irrigation rates

The total amount of water pumped through a tube by a Thelepus specimen was determined in this experiment by measuring the total volume of water pumped in a ventilation chamber (Figure 3) during ten minute intervals. These volumes were measured until a constant flow rate was obtained for one hour.

The volume of water pumped by Thelepus is significantly $(P<0.01)$ when Halosydna occupies the same tube, indicating that the commensal plays a role in changing host irrigation rates. Examination of Table VI indicates that hosts ranging in weight from 1.887 to $5.287 \mathrm{~g}$ all pump less water when the commensal is present in the tube.' In calculating the irrigation rate ( $\mathrm{ml} \mathrm{H}_{2} \mathrm{O}$ pumped/g wet body weight/h), only the wet body weight of Thelepus is used since Halosydna is being tested as a tube obstruction affecting the rate of flow.

At $12.5^{\circ} \mathrm{C}$, the irrigation rate through the tubes decreases by an average of $14.58 \% \pm 7.54 \%$ S.D. when Halosydna lies between the host's body wall and the wall of the tube (Table IV). Further inspection of Table VI reveals that irrigation rates, with a few exceptions, increase when water temperatures are raised to $16.5^{\circ} \mathrm{C}$. The irrigation rates are also depressed to a greater degree at $16.5^{\circ} \mathrm{C}(20.76 \% \pm 8.12 \%$ S.D. $)$ than at $12.5^{\circ} \mathrm{C}$ when commensals are allowed to occupy host tubes.

The percent of depression in the host irrigation rate in the presence 
TABLE VI

A COMPARISON OF THE RATE AT WHICH SEA WATER (33.0\%) IS PUMPED (ML H2 H $_{2}$ WET BODY WEIGHT/H)

BY HOST THELEPUS IN THE PRESENCE AND ABSENCE OF COMMENSAL HALOSYDNA IN

THE HOST TUBE, AT $12.5^{\circ} \mathrm{C}$. (A) AND $16.5^{\circ} \mathrm{C}$. (B)

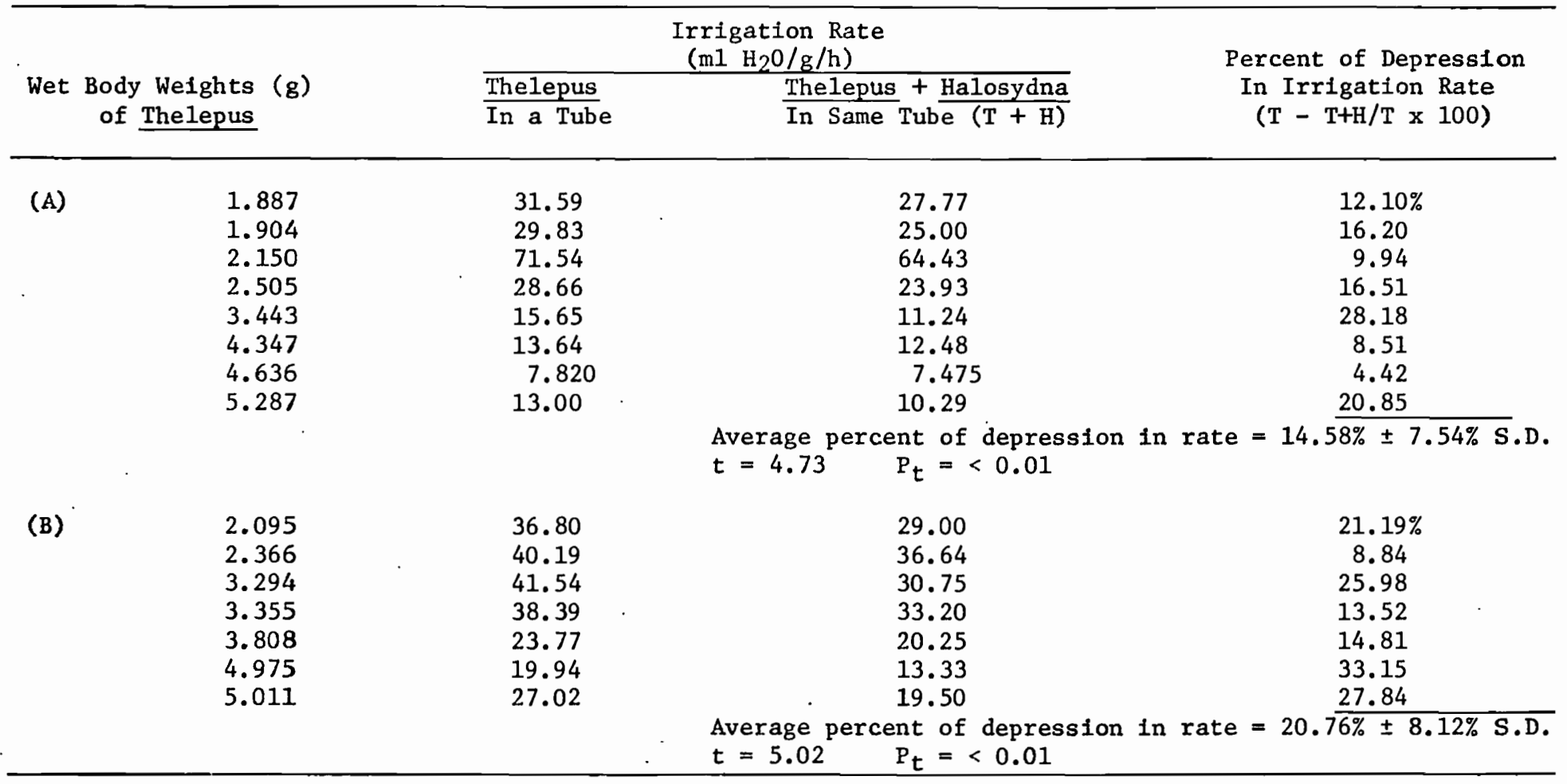

The percent of depression in the rate of irrigation due to presence of Halosydna is measured by ( $\mathrm{T}-\mathrm{T}+\mathrm{H} / \mathrm{T}$ $x$ 100) and is averaged for each temperature.

Pt. Indicates the probability that a difference between the two irrigation rates exists. 
of its commensal ranges from $4.42 \%$ to $28.18 \%$ at $12.5^{\circ} \mathrm{C}$ and $8.84 \%$ to $33.15 \%$ at $16.5^{\circ} \mathrm{C}$. Furthermore, the irrigation rates are not reduced uniformly over the range of weights tested.

It would appear that the physical presence of commensal Halosydna impedes water movement by host Thelepus. By reducing the water flow over the respiratory surfaces of the host, the amount of available oxygen must also be reduced. However, as observed previously, Halosydna does not significantly reduce the rate of oxygen uptake of Thelepus in a tube. The effects of a facsimile of commensal Halosydna on the host's irrigation rates were not tested.

Two specimens of Halosydna $(0.555 \mathrm{gm}$ and $1.100 \mathrm{gm})$, in tubes which had previously contained their original hosts, were used repeatedly to test for commensal water movement through the tube (Figure 3). No detectable volume of water was passed by either commensal over the same temperatures and time periods. 
DISCUSSION

\section{Physiological attractants in commensalism}

The scaleworm Halosydna brevisetosa has been found as a commensal with five terebellid hosts (Table I), two of which are identified by Halosydna by establishing physical contact with the host's tentacles; Neoamphitrite robusta (=Amphitrite robusta) (Davenport and Hickok, 1951) and Thelepus crispus tested here.

Commensal Halosydna establishes contact with host Thelepus in the same manner observed by Davenport (1953b) between three other terebellid hosts and their polynoid commensals. In at least one terebelifd-polynoid relationship, there is evidence that an unstable or closely bound attractant is present on the outside of the host and perhaps the tube material, but apparently is absent in the mucus secreted by the host (Davenport 1953b). Davenport (1953b) also tested scaleworms that are commensal with more than one terebellid host. These commensals showed a specific response to contact with regular hosts, but no response to non-host terebellids. Experiments involving other hosts of Halosydna are needed to determine if Halosydna shows a specificity to one or all of its hosts.

Although Iittle is known about the breeding biology of most polynoids (Daly, 1972), MacGinitie (1939 from Pettibone, 1953) reported gametes maturing in Halosydna during the late spring and summer months at Elkhorn Slough, California. In the present investigation, Thelepus was observed releasing mucus egg sacs in the intertidal in early December at Seal Rock State Park, Oregon. It would seem from this that by the time Halosydna larvae are released, immature Thelepus may already be established in their tubes. Larvae released from under the scales of adult Halosydna (Ricketts and Calvin, 1968) may respond to chemicals 
released by newly metamorphosed adults. Although larval attraction of a commensal to host chemical has not been verified in these species, there have been reports of the existence of Thelepus and Halosydna pairs measuring as little as $30 \mathrm{~mm}$ and $7 \mathrm{~mm}$ long, respectively (Pettibone, 1947; 1953). Thus, host-commensal pairing has been found in very immature annelids and it is assumed that host colonization begins sometime during the early post-embryonic development of both annelids (Pettibone, 1947, 1953; Davenport and Hickok, 1951). We found that pairs of Thelepus and Halosydna are nearly proportional (Figure 4) to each other in size, suggesting that once individuals have paired, they remain together for life. If so, the need for a chemical attractant, released and operating over a distance would be minimal in adult stages.

Although there is little information on how young or larval commensals find their hosts, a large number of sedentary larvae settle gregariously in response to chemicals present from either settled larvae or metamorphosed adults of the same species (reviews by Meadows and Cambe11, 1972). Wilson (1968) confirmed that the gregarious behavior of larvae of Sabellaria alveolatta depends on chemical recognition of the cement

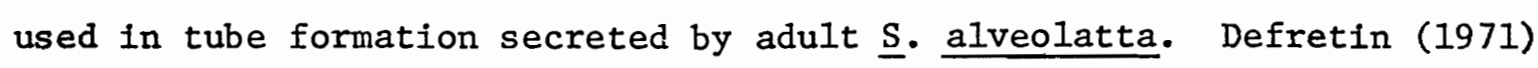
demonstrated that the chemical composition of this cement in tubebullding annelids may vary among species, indicating that the chemicals and larval response to them may be species specific. Since small tubes containing immature Thelepus were found on adult tube colonies of fifty or more at Seal Rock State Park, Oregon. Thelepus larvae may therefore settle in the same gregarious manner. Whether Halosydna larvae are attracted to the cement of host tubes has not been determined. 
There was never more than one commensal Halosydna found in a host tube at the intertidal collection. site. Since Halosydna is a voracious raptor (Ricketts, Calvin and Hedgpeth, 1968), intruders entering the host tube may be consumed. We observed that when several commensals were left in a dish, they would attack one another. Daly (1972) observed that this attacking behavior was high among male adult scaleworms during their breeding season on the English coast.

It is also suggested that other factors may influence commensal existence, Laing, 1937 (from Davenport, 1953b) demonstrated that two parasitic insects are attracted to an environment likely to contain their hosts by qualities of the environment itself, without the host present. A review of early work with free-living benthic organisms revealed that the substrate has an important influence on the settlement of larvae (reviewed by Davenport, 1955). Larvae of organisms of a specific habit are sensitive to minute differences in the environment and they actually sample the substrate before settling. The habitat that an animal selects may also depend on its age, its physiological state, its learning and previous experience and its past and present environment (Meadows and Cambel1, 1972). Whether Halosydna uses any of these means in colonizing and maintaining a commensal relationship with Thelepus can only be determined by settlement and metamorphosis studies.

\section{Host-Commensal Behavior Within the Tube}

There is evidence that Halosydna may benefit from the water flow produced by Thelepus in the tube by assuming a characteristic position along the dorsum of the host's body with its anterior-posterior orientation opposite to that of the host. Halosydna uses its epidermal cilia 
and scales to direct oxygenated water posteriorly over its thin dorsum to facilitate oxygen consumption (Lwebuga-Mukasa, 1970). Since commensals were always observed to be directed into the host's inhalent water flow, both worms pass water in the same direction. Lwebuga-Mukasa (1970) suggests that host tubes may enhance rather than diminish the water directing action of the scales and cilia in Halosydna.

Halosydna (without their hosts) responds to changes in the direction of the water flow through a tube by reversing its body direction so that its anterior end is pointing into the oncoming water current. Therefore, It would seem that Halosydna's orientation is the result of the host's water current rather than the host itself, since similar behavior is observed when a host and commensal occupy the same tube. There are cases where Thelepus itself reverses the current in the tube (Dales, 1961b) but the period is not long enough to test the reversing behavior of Halosydna.

Webster (1969) reports a similar situation for the scaleworm Arctonoë vittata commensal with the large chiton Cryptochiton stelleri. Scaleworms resting in the pallial grooves of the chiton are always found in the inhalent respiratory current. Aside from the provision of a continuous supply of food and protection, this position provides oxygenated sea water on which to respire. The host Thelepus may be responsible for part of Halosydna's orientation behavior can not be ignored.

Oxygen Consumption and Irrigation Rates in Commensals

It has been fully demonstrated in a wide variety of poikilotherms that the line relating $\log$ metabolism to $\log$ body weight has a slope (b) of approximately 0.75 (for review see Zeuthen, 1953; Hemmingsen, 1960). 
However, this slope can be as high as 1.0 or near zero for some species. Mangum (1963) reveals that these authors did not consider the slope to be temperature-sensitive. Evidence is presented by Newell (1973) and Mangum (1963) that the value of the slope in many invertebrates varies according to temperature and other external conditions. This can be seen. in the lower values the slope obtained in some marine annelids: 0.478 in the maldanid polychaete Clymenella torquata at $23.5^{\circ} \mathrm{C}$. (Mangum, 1963) and 0.407 and 0.544 at $26.5^{\circ} \mathrm{C}$. in the polychaetes Hermodice carunculata and Sabellastarte magnifica, respectively (Sander, 1973). The values of the slope at $12.5^{\circ} \mathrm{C}$ and $16.5^{\circ} \mathrm{C}$ for Thelepus $(0.714$ and 0.743 respectively and Halosydna $(0.507$ and 0.709 respectively) are near 0.75 , in all but one case. Other factors such as activity, body size, photoperiod and salinity were controlled in these experiments. However, respiration data is also a function of factors that are difficult to control such as the nutritive level, season, sexual maturity and the ebb and flow of the tide (Prosser, 1973; Newell, 1973).

Oxygen consumption rates calculated for Thelepus are similar to rates found in the literature. Dales (1961b) calculated that a $3.0 \mathrm{~g}$ specimen of Thelepus consumed approximately $0.06 \mathrm{ml} 0_{2} / \mathrm{g} / \mathrm{h}$ in a tube at $12-13^{\circ} \mathrm{C}$ (salinity not reported). Similarly, it can be seen from Figure 5, that a Thelepus specimen of the same size, at a salinity of $33.0 \%$, consumed approximately $0.04 \mathrm{ml} 0_{2} / \mathrm{g} / \mathrm{h}$ in a tube at $12.5^{\circ} \mathrm{C}$. Furthermore, the slope of weight-specific oxygen consumption in Thelepus from Dales (1961b) $(-0.24)$ and that from Figure $5(-0.2568)$ are virtually the same. We were unable to show a significant difference between the respiration rates of a number of host Thelepus in individual cultures and the 
same host specimens with their commensals in mixed cultures.

In contrast, when three species of fresh water sludge worms were mixed in a container, the growth and respiration rates (m1 $0_{2} / \mathrm{mg}$ dry wt/h) differed from the sum of the rates obtained from the same species in pure culture (Brinkhurst et al., 1972). Although these oligachaetes are not considered commensals, their colonies are tightly clumped in field cultures in the mud along lake bottoms. These mixed colonies may contain up to 12 species. These three species selectively ingest sedimentary material and differ in their ability to digest a number of aerobic bacteria (Brinkhurst et al., 1972). These investigators also suggest that the feces and bacteria of one worm might be the preferred food of a second species from the same habitat.

In later experiments, with the same worms, in which groups (10 to 20 of each species) of two species are separated only by Nitex screen, the respiration rates of the pairs are significantly lower $(P<0.01)$ than the sums of the respiration rates of the same individuals in pure cultures (Chua and Brinkhurst, 1973). A similar situation may exist (Figure 5) between the regression lines representing the oxygen consumption rate of host Thelepus in pure and in mixed cultures with Halosydna. Although the distance between the regression lines is not significant, there are individual cases where a host Thelepus specimen consumes more oxygen than the same host with its commensal (Appendix I). The change in oligochaete respiration is explained by Chua and Brinkhurst (1973) as follows. It is possible to see that worms seek out worms of another species through recognition of dissolved metabolites released in the excreta. Oligochaetes from pure cultures might be ex- 
pected to show an increase in their respiration rate as a consequence of their colony-seeking activity. Once colonies have been located by a species, their searching activity may decline and their growth rates may consequently increase, particularly if species have found their preferred food.

An individual specimen of Halosydna consumes much less oxygen than a host with which it is normally found. This difference can be shown by examination of Appendix I.

Halosydna consumes an average of $23 \% \pm 6.06 \% \mathrm{S.D}$. (at $16.5^{\circ} \mathrm{C}$ ) to $33 \% \pm 9.87 \% \mathrm{~S} . \mathrm{D} .\left(\right.$ at $12.5^{\circ} \mathrm{C}$ ) of the total oxygen consumed in a mixed culture, assuming that the respiration rates for each species in pure cultures do not change when combined in a mixed culture. The comnensal also seems to consum more oxygen at $12.5^{\circ} \mathrm{C}$ than at $16.5^{\circ} \mathrm{C}$. However, it is not known if commensal Halosydna or Thelepus actually consume more or less oxygen when both species occupy the same tube.

Results obtained in the present study indicate that the irrigation activity of Thelepus, in a mixed culture, is constantly depressed due to the physical presence of Halosydna within the tube. Halosydna alone in the host tube does not pass a measurable amount of water. It is estimated that the irrigation rates at $12.5^{\circ} \mathrm{C}$ for a $3.0 \mathrm{gm}$ specimen of Thelepus in a tube is $21.5 \mathrm{ml} \mathrm{H} 20 / \mathrm{g} / \mathrm{h}$, while Dales (1961b) calculated $12.6 \mathrm{cc} \mathrm{H} \mathrm{H}_{2} \mathrm{O} / \mathrm{g} / \mathrm{h}$ (no salinity reported) for a Thelepus under the same conditions. Differences in these rates may be due to the use of another apparatus in measuring rates of irrigation as well as the possible difference in the salinity used in both experiments. Another terebellid, Eupolymnia heterobranchia, is sometimes found 
in the same geographic area as Thelepus, but has a rate of oxygen uptake and Irrigation twice that of Thelepus (Dales, 1961b). Since Eupolymnia has a low oxygen affinity hemoglobin (Manwel1, 1959, from Dales 1961b), these worms may resort to aerial respiration when their burrows are revealed by the tide. Their high irrigation and respiration rate may serve to compensate for the lack of a high oxygen affinity pigment and for the low oxygen environment of decaying organic material in which they are usually found (Dales, 1961b).

Thelepus has two hemoglobins; one which is found in the coelomic cells, has a high affinity for oxygen $\left(P_{50}=3.13 \mathrm{~mm} \mathrm{Hg} \pm 0.02\right.$ at $20^{\circ} \mathrm{C}$ and $\mathrm{pH}$ 7.0), and the other, an extracellular vascular hemoglobin with a lower oxygen affinity $\left(\dot{\mathrm{P}}_{50}=29.52 \mathrm{~mm} \mathrm{Hg} \pm 2.55\right.$ at $20^{\circ} \mathrm{C}$ and $\left.\mathrm{pH} 7.0\right)$ (Unpublished data, Garlick, R., personal communications). The presence of a high oxygen affinity pigment in Thelepus may enable the species to respire at very low partial pressure of oxygen (mm Hg) such as during tidal exposure. Halosydna has a neurohemoglobin found in the cells of the brain and ventral nerve cord and has a fairly high affinity for oxygen $\left(P_{50}=15 \mathrm{~mm} \mathrm{Hg}\right)$ (Manwe11, 1960; Wittenberg et al., 1965), indicating that this commensal can also survive in a low oxygen environment for a period of time.

Peterson and Johansen (1969) noted that the tubes of Mesochaetopterous taylori are impermeable to. water and oxygen and that these worms nearly exhaust their oxygen supply during an average 3-hour tidal period. Although Thelepus tubes, stripped of debris, are fragile, several were able to hold water without leaking. In Figure 7, a $2.2 \mathrm{~g}$ Thelepus consumes $52 \%$ of its available oxygen from a $130 \mathrm{ml}$ chamber in 3 hours at 
$12.5^{\circ} \mathrm{C}$. A $2.6 \mathrm{~g}$ Thelepus consumes $84 \%$ of its available oxygen at $16.5^{\circ} \mathrm{C}$. under the same conditions. However, two large Halosydna (1.12 and 1.44 g) consume only $19 \%$ and $24 \%$ at the same respective temperatures during a 3 hour period. Dales (1961b) estimated that Eupolymnia and Thelepus ut1lize 50 to $60 \%$ of their available oxygen at 12 to $13^{\circ} \mathrm{C}$ when the oxygen concentration is high $\left(7.0 \mathrm{~m} 10_{2} / L\right)$, which tends to support the previous data at $12.5^{\circ} \mathrm{C}$.

Thelepus and Halosydna both have respiration rates that seem to be directly dependent on the oxygen concentrations in their surrounding environment (Figure 7). However, these preliminary studies do not preclude further investigations of the effects of low oxygen concentration in their surrounding environment (Figure 7). However, these studies do not preclude further investigations of the effects of low oxygen concentrations on commensal behavior and respiration of Thelepus and Halosydna. 


\section{BIBLIOGRAPHY}

Barnes, H. 1959. Determination of salinity of sea water. Pages 84-98 in Apparatus and methods in oceanography. Interscience Publishers, Inc., New York.

Barnes, R. D. 1968. Invertebrate Zoology. Pages 204-248. W. B. Saunders Co., Philadelphia.

Bartel, A. H. and D. Davenport. 1956. A technique for the investigation of chemical responses in aquatic animals. Anim. Behav. 4:117-119.

Brinkhurst, R. O., K. E. Chua, and N. K. Kaushik. 1972. Interspecific interactions and selective feeding by tubificid oligochaetes. Limno1. Oceanogr. 17:122-133.

Brown, P. L. and D. V. Ellis. 1971. Relation between tube-building and feeding in Neoamphitrite robusta (Polychaete: Terebellidae). J. Fish. Res. Board Can. 28:1433-1435.

Cheng, T. C. 1967. Marine molluscs. as hosts for symbioses: with a review of known parasites of commercially important species. 5:9 in F. S. Russe11, ed. Avd. Mar. Biol. Academic Press, London.

Chua, K. E. and R. O. Brinkhurst. 1973. Evidence of interspecific interactions in the respiration of tubificid oligochaetes. J. Fish. Res. Board. Can. 617-622.

Clark, R. B. 1956. Capitella capitata as a commensal, with a bibliography of parasitism and commensalism in the polychaetes. Ann Mag. Nat. Hist. Ser. 12, 2:433-448.

Dales, R. P. 1955. Feeding and digestion in terebellid polychaetes. J. Mar. Biol. Ass. U. K. 34:55-79.

Dales, R. P. 1957. Interrelations of organisms A. Commensalism. In Treatise on marine ecology and paleontology. J. W. Hedgpeth ed. Geol. Soc. Amer. Mem. 67:391-412.

Dales, R. P. 1961a. Observations on the respiration of the sabellid polychaete Schizobrachia insiqnis. Biol. Bull. (Woods Hole) 121:82-9I.

Dales, R. P. 1961b. Oxygen uptake and irrigation of the burrow by three terebellid polychaetes: Eupolymnia, Thelepus and Neoamphitrite. Physiol. Zool. 34:306-311.

Dales, R. P. 1970. General behavior and commensalism. 200 pages in Annelids. Hutchison and Co., London.

Dales, R. P., C.P. Mangum and J. C. Tichy. 1970. Effects of changes in oxygen and carbon dioxide concentrations on ventilation rhythms in onuphid polychaetes. J. Mar. Biol. Assoc. U. K. 50:365-380. 
Daly, J. M. 1972. The maturation and breeding biology of Harmothoë imbricata (Polychaeta: Polynoidae). Mar. Biol. (Ber1). 12:53-66.

Davenport, D. 1950. Studies in the physiology of commensalism. 1. The polynoid genus Arctonoë. Bio1. Bull. (Woods Hole). 98:81-93.

Davenport, D. 1953a. Studies in the physiology of commensalism. III. The polynoid genera Acholoë, Gattyana and Lepidasthenia. J. Mar. Biol. Assoc. U. K. 32:161-173.

Davenport, D. 1953b. Studies in the physiology of commensalism. IV. The polynoid genera Polynoe, Lepidasthenia and Harmothoë. J. Mar. Biol. Assoc. U. K. 32:273-288.

Davenport, D. 1955. Specificity and behavior in symbioses. Q. Rev. Biol. $30: 29-46$.

Davenport, D., G. Camougis and J. F. Hickok. 1960. Analysis of the behavIor of commensals in host-factor. 1. A hesionid polychaete and pinnotherid crab. Anim. Behav. 8:209-218.

Davenport, D. and Hickok, J. K. 1951. Studies in the physiology of commensalism. 2. The polynoid genera Arctonoë and Halosydna. Bio1. Bull. (Woods Hole). 100:71-83.

Davenport, D. and Hickok, J. F. 1957. Notes on the early stages of the facultative commensal Podarke pugettensis Johnson (Polychaeta: Hesionidae) Ann. Mag. Nat. Hist. Ser. 12 10:625-631.

Defretin, R. 1971. The tubes of polychaete annelids. Ser. C, 26:713746 in M. Florkin and E. Stotz, eds. Comprehensive biochemistry; extracellular and supporting structures. Elsevier Publishing Co., Amsterdam.

Garlick, R. 1973. Personal communications.

Green, E. J. and D. E. Carrit. 1967. New tables for oxygen saturation of sea water. J. Mar. Res. 25:140-147.

Gonor, J. J:, A. B. Thum and D. W. Elvin. 1970. Inshore sea surface temperatures ano salinity conditions at Agate Beach, Yaquina Bay and Whale Cove, Oregon, in 1970. A technical report to the Office of Naval Research. Oregon State University, Department of Oceanography, data report no. 45 on Office of Naval Research Contract N00014-67-A-0369-0001, Project NR 104 936, 30 numbered leaves.

Gerber, H. S. and J. F. Stout. 1968. Sensory basis of the symbiotic relationship of Arctonoë vittata (Grube) (Polychaeta, Polynoidae) to the keyhole limpet, Diadora aspera. Physiol. Zoo1. 41:169-179. 
Hartman, 0. 1951. Complete listing of the literature on polychaetes from Linnaeus. Pages 1758-1959 in Vol. 1 Literature of the Polychaete Annelids. Allan Hancock Foundation Publishers.

Hartmann-Schröder, G. 1960. Zur polychaeten Fauna von Peru. Beitr. Neotrop. Fauna. 2:1-44.

Hemmingsen, A. M. 1960. Energy metabolism as related to body size and respiratory surfaces, and its evolution. Report of the Steno Memorial Hospital and Nordisk Insulinlaboratorium. 9:1-110.

Hickok, J. F. and D. Davenport. 1957. Further studies in the behavior of commensal polychaetes. Biol. Bull. (Woods Hole). 113:397-406.

Hoffman, R. J. and C. P. Mangum. 1970. The function of coelomic cell hemoglobin in the polychaete Glycera dibranchiata. Comp. Biochem. Physiol. 36:211-228.

Lwebuga-Mukasa, J. 1971. The role of elytra in the movement of water over the surface of Halosydna brevisetosa (Polychaeta: Polynoidae) Bul1. South. Calif. Acad. Sci. 69(3/4):154-160.

MacCinitie, G. E. and N. MacGinitie. 1968. Natural history of marine animals. Pages 208-213, 464-465. McGraw-Hill Book Co., New York.

Mangum, C. P. 1963. Studies on speciation in maldanid polychaetes of the North American Atlantic Coast - III. Intraspecific and interspecific divergence in oxygen comsumption. Comp. Biochem. Physiol. 10:335-349.

Mangum, C. P. 1964. Activity paterns in metabolisms and ecology of polychaetes. Comp. Biochem. Physiol. 11:239-256.

Mangum, C. P. 1970.' Respiratory physiology in annelids. Am. Sci. 58: 641-647.

Mangum, C. P., and W. Van Winkle. 1973. Responses of aquatic invertebrates to declining oxygen conditions. Amer. Zoo1. 13:529.

Mangum, C. P. and C. Sassaman. 1969. Temperature sensitivity of active and resting metabolism in a polychaetous annelid. Comp. Biochem. Physio1. 30:111-116.

Manwe11, C. 1960. Heme-heme interactions in the oxygen equilibrium of some invertebrate myoglobins. Arch. Biochem. Biophy. 89:194-201.

May, D. R. 1972. The effects of oxygen concentration and anoxia on respiration of Abarenicola pacifica and Lumbrineris zonata (Polychaeta). Bio1. Bul1. (Woods Hole). 142:71-83. 
Meadows, P. S. and J. I. Cambe11. 1972. Habitat selection by aquatic invertebrates. 10:271-382 in F. S. Russell and M. Yonge, eds. Adv. Mar. Biol. Academic Press, Inc., London.

Newe11, R. C. 1973. Factors affecting the respiration of intertidal invertebrates. Am. Zoo1. 13:513-528.

Orton, J. H. and C. L. Smith. 1935. Experiments with Amphitrite and its commensals. Ann. Mag. Nat. Hist. Ser. 10, $\overline{16: 644-645 .}$

Peterson, J. A. and K. Johansen. 1969. Aspects of oxygen uptake in Mesochaetopterus taylori, a tube-dwelling polychaete. Biol. Bull. (Woods Hole). 133:600-605.

Pettibone, M. H. 1947. Polychaetous annelids of the Superfamily Aphroditoidea from the San Juan Archipelago, Puget Sound, and adjacent waters. Unpublished doctoral dissertation. Univ. of Wash. Pages 25-35.

Pettibone, M. H. 1953. Some scale-bearing polychaetes of Puget Sound and adjacent waters. Pages 16-20, 80-82, plates 3-5. University of Washington Press, Seattle.

Prosser, C. L. 1973. Oxygen: Respiration and metabolism. Pages 317356 in C. L. Prosser, Comparative animal physiology. W. B. Saunders Co., Philadelphia.

Ricketts, E. F., J. Calvin and J. W. Hedgpeth. 1968. Between pacific tides. Stanford University press, California. 614 pp.

Sander, F. 1973. A comparative study of respiration in two tropical marine polychaetes. Comp. Biochem. Physio1. 46:311-323.

Segrove, F. 1938. An account of surface ciliation of some polychaete worms. Proc. Zoo1. Soc. Land. Ser. B, 108:85-106.

Snedecor, G. W. and W. G. Cochran. 1967. Analysis of covarience. Pages 419-446 in G. W. Snedecor, Statistical methods. Iowa State University Press, Iowa.

Webster, K. 1969. An investigation of commensals Chryptochiton stelleri (Middendorff, 1846) in the Monterey Peninsula Area, California Veliger. 11:121-125.

Wilson, D. P. 1968. The settlement behavior of the larvae of Sabellaria alveolata (L.). J. Mar. Biol. Assoc. U. K. 48:387-435.

Wittenberg, B. A., R. W. Brieh1 and J. B. Wittenberg. 1965. Haemoglobins of invertebrate tissues; nerve haemoglobins of Aphrodite, Aplysia and Halosydna. Biochem. J. 96:363-371. 
Zeuthen, E. 1953. Oxygen uptake as related to body size in organisms. Q. Rev. Bio1. 28:1-1.2. 
APPENDIX I

A summary of points from the data in Figures 5 and 6 which are fitted to the regression lines at $12.5^{\circ} \mathrm{C}$ and $16.5^{\circ} \mathrm{C}$.

\begin{tabular}{|c|c|c|c|c|c|c|c|c|c|c|}
\hline \multirow[b]{2}{*}{$\begin{array}{l}\text { Trial } \\
\text { Number }\end{array}$} & \multicolumn{3}{|c|}{$\begin{array}{c}\text { Thelepus in a tube } \\
(\mathrm{T})\end{array}$} & \multicolumn{3}{|c|}{$\frac{\text { Thelepus } \& \text { Halosydna }}{\text { in the same tube }}$} & \multicolumn{3}{|c|}{$\frac{\text { Halosydna in a tube }}{(H)}$} & \multirow{2}{*}{$\begin{array}{l}\text { Amount of Oxygen Consumed } \\
\left(\mathrm{ml} \mathrm{O}_{2} / \mathrm{h}\right) \text { by Halosydna in a } \\
\text { mixed culture of Thelepus }+ \\
\text { Halosydna in the same tube } \\
(\mathrm{H} / \mathrm{T}+\mathrm{H} \times 100=\%)\end{array}$} \\
\hline & $\begin{array}{l}\text { Wet We1ght } \\
(\mathrm{g})\end{array}$ & $\begin{array}{l}\mathrm{O}_{2} \mathrm{C} \\
\mathrm{ml} \mathrm{O}_{2} / \mathrm{h}\end{array}$ & $\begin{array}{l}\text { sumption } \\
\text { mI } 0_{2} / g / h\end{array}$ & $\begin{array}{l}\text { Combined } \\
\text { Wet WeIght } \\
(g)\end{array}$ & $\mathrm{m} 1 \mathrm{O}_{2} \mathrm{O} / \mathrm{h}$ & $\begin{array}{l}\mathrm{ml} \mathrm{O}_{2} / \mathrm{g} / \mathrm{h} \\
\mathrm{n}\end{array}$ & $\begin{array}{l}\text { Wet Weight } \\
\text { (g) }\end{array}$ & $\mathrm{ml} \quad \begin{array}{l}0_{2} \mathrm{Cc} \\
0_{2} / \mathrm{h}\end{array}$ & ml $0_{2} / g / h$ & \\
\hline \multicolumn{11}{|l|}{$12.5^{\circ} \mathrm{C}$} \\
\hline $\begin{array}{r}1 \\
2 \\
3 \\
4 \\
5 \\
6 \\
7 \\
8 \\
9 \\
10 \\
11\end{array}$ & $\begin{array}{l}2.870 \\
3.313 \\
4.023 \\
1.690 \\
4.658 \\
2.640 \\
2.555 \\
6.653 \\
1.355 \\
0.891 \\
2.21\end{array}$ & $\begin{array}{l}0.158 \\
0.141 \\
0.174 \\
0.081 \\
0.144 \\
0.079 \\
0.094 \\
0.254 \\
0.061 \\
0.056 \\
0.131\end{array}$ & $\begin{array}{l}0.055 \\
0.043 \\
0.043 \\
0.048 \\
0.031 \\
0.030 \\
0.037 \\
0.038 \\
0.045 \\
0.064 \\
0.059\end{array}$ & $\begin{array}{l}3.501 \\
4.004 \\
5.097 \\
2.387 \\
5.156 \\
3.600 \\
3.492 \\
7.835 \\
1.769 \\
1.222 \\
2.730\end{array}$ & $\begin{array}{l}0.141 \\
0.168 \\
0.168 \\
0.113 \\
0.150 \\
0.097 \\
0.114 \\
0.255 \\
0.088 \\
0.066 \\
0.155\end{array}$ & $\begin{array}{l}0.040 \\
0.042 \\
0.033 \\
0.047 \\
0.030 \\
0.027 \\
0.033 \\
0.033 \\
0.049 \\
0.054 \\
0.057\end{array}$ & $\begin{array}{l}0.633 \\
0.691 \\
1.075 \\
0.696 \\
0.408 \\
0.959 \\
0.837 \\
0.182 \\
0.415 \\
0.331 \\
0.520\end{array}$ & $\begin{array}{l}0.031 \\
0.044 \\
0.048 \\
0.046 \\
0.048 \\
0.055 \\
0.036 \\
0.055 \\
0.027 \\
0.027 \\
0.034\end{array}$ & $\begin{array}{l}0.049 \\
0.064 \\
0.045 \\
0.067 \\
0.096 \\
0.057 \\
0.044 \\
0.046 \\
0.066 \\
0.083 \\
0.066\end{array}$ & $\begin{array}{ll}22 \% \\
26 \\
29 \\
41 \\
32 \\
56 \\
31 \\
32 \\
31 \\
41 \\
22 \\
\end{array}$ \\
\hline \multicolumn{11}{|r|}{-} \\
\hline $\begin{array}{r}1 \\
2 \\
3 \\
4 \\
5 \\
6 \\
7 \\
8 \\
9 \\
10 \\
11 \\
12 \\
13 \\
14\end{array}$ & $\begin{array}{l}4.011 \\
4.645 \\
1.718 \\
2.582 \\
4.237 \\
3.877 \\
2.280 \\
1.747 \\
5.709 \\
4.015 \\
3.582 \\
2.114 \\
5.366 \\
2.843\end{array}$ & $\begin{array}{l}0.221 \\
0.250 \\
0.129 \\
0.200 \\
0.239 \\
0.177 \\
0.138 \\
0.105 \\
0.358 \\
0.200 \\
0.231 \\
0.187 \\
0.233 \\
0.152\end{array}$ & $\begin{array}{l}0.055 \\
0.054 \\
0.075 \\
0.078 \\
0.056 \\
0.046 \\
0.061 \\
0.060 \\
0.063 \\
0.050 \\
0.066 \\
0.089 \\
0.043 \\
0.054\end{array}$ & $\begin{array}{l}4.791 \\
6.225 \\
2.580 \\
3.363 \\
5.038 \\
5.480 \\
2.501 \\
2.434 \\
6.531 \\
4.886 \\
4.893 \\
2.911 \\
6.269 \\
3.365\end{array}$ & $\begin{array}{l}0.249 \\
0.348 \\
0.109 \\
0.220 \\
0.244 \\
0.210 \\
0.131 \\
0.194 \\
0.292 \\
0.191 \\
0.236 \\
0.191 \\
0.276 \\
0.171\end{array}$ & $\begin{array}{l}0.052 \\
0.056 \\
0.042 \\
0.065 \\
0.048 \\
0.038 \\
0.052 \\
0.080 \\
0.045 \\
0.040 \\
0.048 \\
0.065 \\
0.044 \\
0.051\end{array}$ & $\begin{array}{l}0.780 \\
1.578 \\
0.863 \\
0.781 \\
0.847 \\
1.604 \\
0.221 \\
0.688 \\
0.822 \\
0.871 \\
1.311 \\
0.797 \\
0.903 \\
0.522\end{array}$ & $\begin{array}{l}0.041 \\
0.082 \\
0.038 \\
0.044 \\
0.050 \\
0.063 \\
0.020 \\
0.041 \\
0.041 \\
0.054 \\
0.068 \\
0.047 \\
0.044 \\
0.027\end{array}$ & $\begin{array}{l}0.053 \\
0.052 \\
0.044 \\
0.057 \\
0.060 \\
0.040 \\
0.093 \\
0.060 \\
0.050 \\
0.627 \\
0.052 \\
0.060 \\
0.043 \\
0.052\end{array}$ & $\begin{array}{l}17 \% \\
24 \\
35 \\
20 \\
25 \\
30 \\
15 \\
21 \\
21 \\
28 \\
29 \\
25 \\
16 \\
16 \\
\end{array}$ \\
\hline
\end{tabular}


APPENDIX II

Statistical Treatment of the Data

Metabolism, in general, is more uniformly expressed as a power function of body size (Prosser, 1972). If $\mathrm{R}$ is the oxygen consumption per hour (respiration rate) and $W$ is the wet body weight, then

$$
\mathrm{R}=\mathrm{KW} \mathrm{b}
$$

and

$$
\log R=\log K+b \log W
$$

where $b$ is obtained from the siope of a regression line of log. oxygen consumption against log. weight and $K$ from the $y$-intercept. A straight line with a positive slope is given over a range of weights.

For weight-specific oxygen consumption,

$$
\mathrm{R} / \mathrm{W}=\mathrm{KW}^{\mathrm{b}-1}
$$

and

$$
\log (R / W)=\log K+(b-I) \log W
$$

Such a plot yields a straight line with a negative slope. Regression Iines relating oxygen uptake to body size were fitted by the method of least squares.

The comparison of regression lines are treated by the analysis of covariance (Snedecor, 1967) to determine statistically significant differences in the slopes, where

$$
F(1)=\frac{\text { mean squares for regression coefficient }}{\text { mean squares of within samples }}
$$

and the levels on the ordinant, where

$$
F(2)=\frac{\text { mean squares for adjusted means }}{\text { mean squares for common means }}
$$

Correlation coefficients ( $r$ ) are calculated for each regression 
line for which t-tests are carried out to see if coefficients are significantly different from zero. 


\section{APPENDIX III}

Calculations for the location of the regression line in relation to the smallest host-commensal pair weighed.

The wet body weight of Halosydna is expressed as a power function of the wet body weight of Thelepus. Using the values for the slope (b) and $y$-intercept (a) already calculated from the regression line,

where

$$
\begin{aligned}
& Y=a x^{b} \\
& Y=0.221(x)^{0.9167}
\end{aligned}
$$

The specimen of Halosydna weighs 0.01 gms and Thelepus 0.03 gms. Thelepus is plugged into the " $\mathrm{x}$ " position and solved for " $\mathrm{Y}$ ".

$$
\begin{aligned}
\log Y & =\log 0.221+(0.9167) \log 0.03 \text { gms. } \\
\log Y & =-1.5096+(0.9167)(-3.5066) \\
\log Y & =-4.7240 \\
e^{-X} & =0.0089 \text { gins. } \quad \text { (Halosydna) }
\end{aligned}
$$

This value of $8.9 \mathrm{mgs}$. is very close to $10 \mathrm{mgs}$. Which is the actual wet body weight of Halosydna. 